\title{
LEVEL II SCOUR ANALYSIS FOR BRIDGE 34 (CORITH00500034) on TOWN HIGHWAY 50, crossing the SOUTH BRANCH WAITS RIVER, CORINTH, VERMONT
}

Open-File Report 97-671

Prepared in cooperation with

VERMONT AGENCY OF TRANSPORTATION

and

FEDERAL HIGHWAY ADMINISTRATION

U.S. Department of the Interior

U.S. Geological Survey

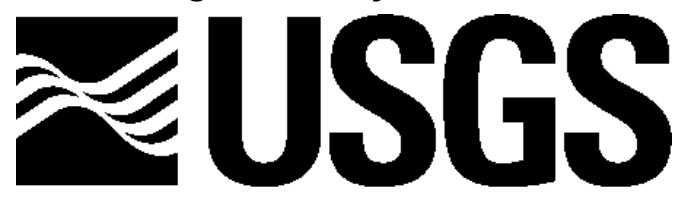

science for a changing world 


\section{LEVEL II SCOUR ANALYSIS FOR BRIDGE 34 (CORITH00500034) on TOWN HIGHWAY 50, crossing the SOUTH BRANCH WAITS RIVER, CORINTH, VERMONT \\ By MICHAEL A. IVANOFF}

U.S. Geological Survey Open-File Report 97-671

Prepared in cooperation with

VERMONT AGENCY OF TRANSPORTATION

and

FEDERAL HIGHWAY ADMINISTRATION 


\title{
U.S. DEPARTMENT OF THE INTERIOR BRUCE BABBITT, Secretary
}

\author{
U.S. GEOLOGICAL SURVEY \\ Mark Schaefer, Acting Director
}

For additional information write to:

District Chief

U.S. Geological Survey 361 Commerce Way

Pembroke, NH 03275-3718
Copies of this report may be purchased from:

U.S. Geological Survey

Branch of Information Services

Open-File Reports Unit

Box 25286

Denver, CO 80225-0286 


\section{CONTENTS}

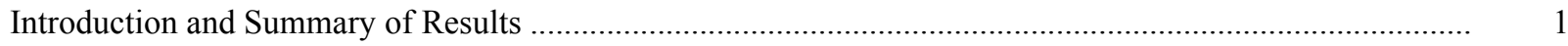

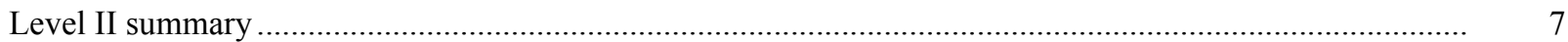

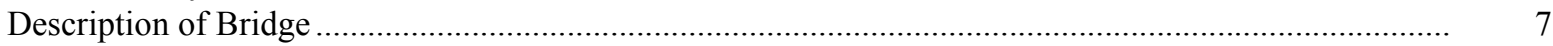

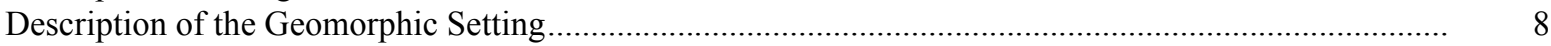

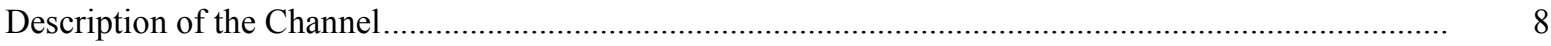

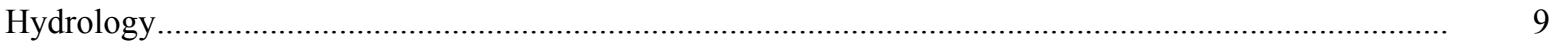

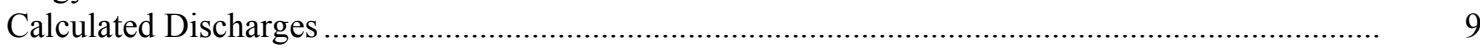

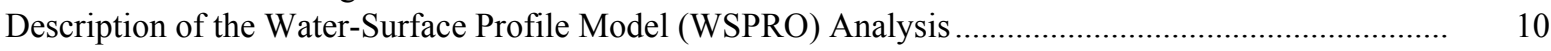

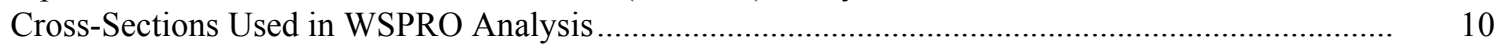

Data and Assumptions Used in WSPRO Model ...................................................................... 11

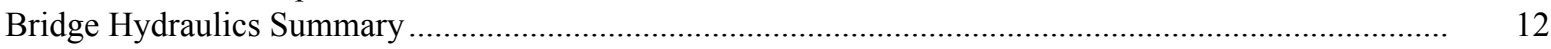

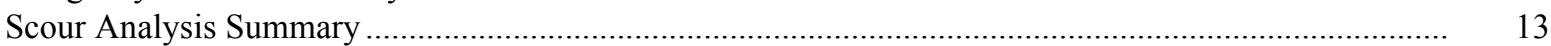

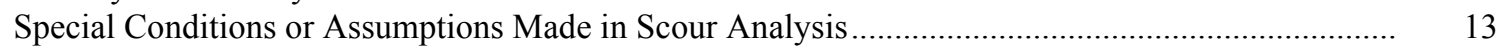

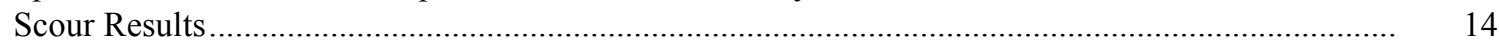

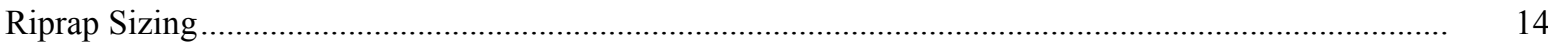

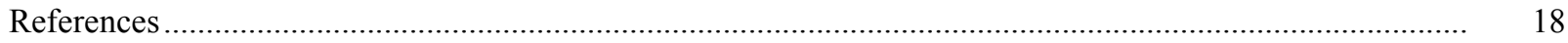

Appendixes:

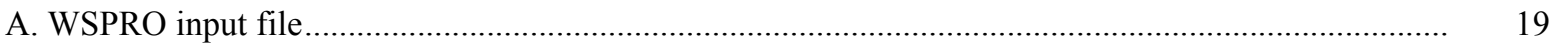

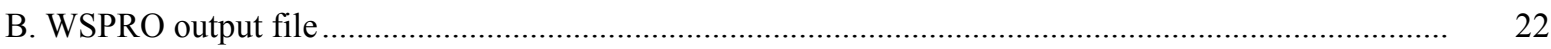

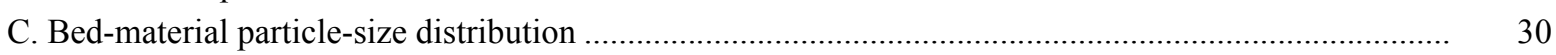

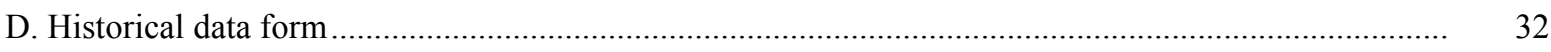

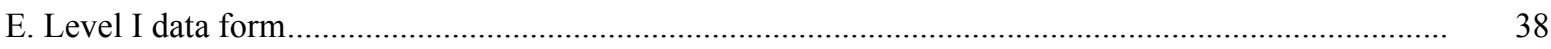

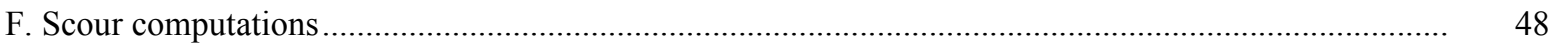

\section{FIGURES}

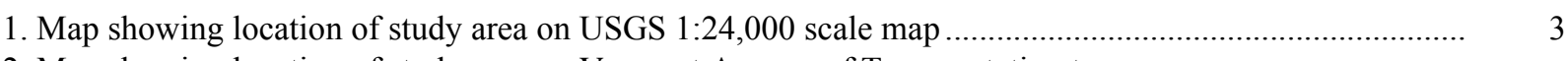

2. Map showing location of study area on Vermont Agency of Transportation town
highway map

3. Structure CORITH00500034 viewed from upstream (September 5, 1995) ........................................... 5

4. Downstream channel viewed from structure CORITH00500034 (September 5, 1995).......................... 5

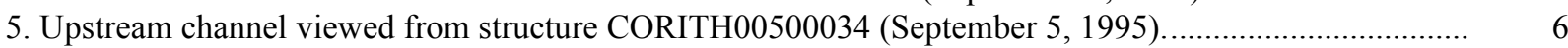

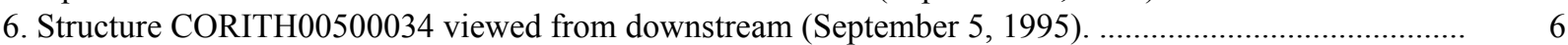

7. Water-surface profiles for the 100- and 500-year discharges at structure

CORITH00500034 on Town Highway 50, crossing the South Branch Waits River,

Corinth, Vermont.

8. Scour elevations for the 100- and 500-year discharges at structure

CORITH00500034 on Town Highway 50, crossing the South Branch Waits River,

Corinth, Vermont.

\section{TABLES}

1. Remaining footing/pile depth at abutments for the 100-year discharge at structure

CORITH00500034 on Town Highway 50, crossing the South Branch Waits River,

Corinth, Vermont

2. Remaining footing/pile depth at abutments for the 500-year discharge at structure

CORITH00500034 on Town Highway 50, crossing the South Branch Waits River,

Corinth, Vermont 


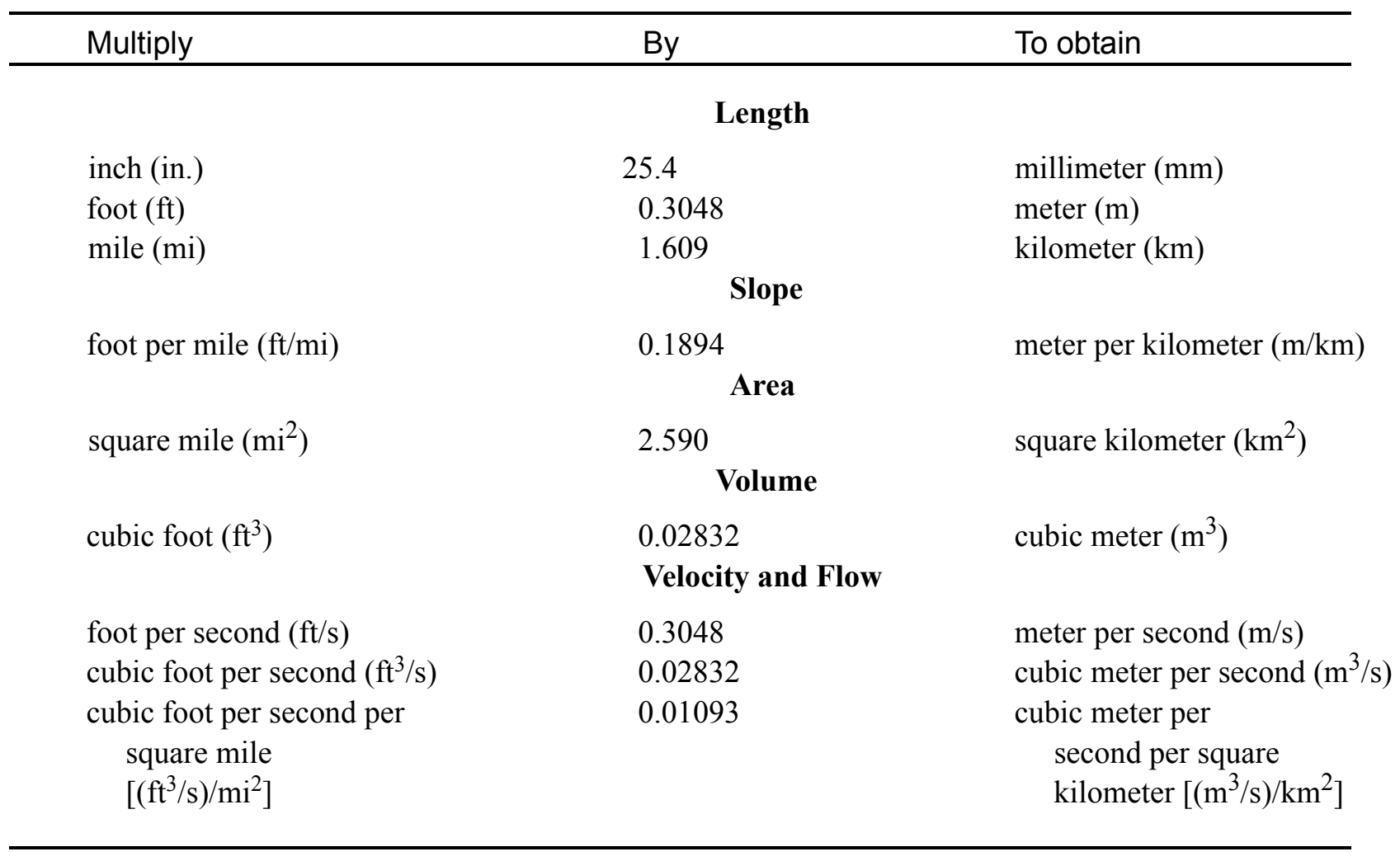

\section{OTHER ABBREVIATIONS}

$\begin{array}{lrlr}\mathrm{BF} & \text { bank full } & \text { LWW } & \text { left wingwall } \\ \mathrm{cfs} & \text { cubic feet per second } & \text { MC } & \text { main channel } \\ \mathrm{D}_{50} & \text { median diameter of bed material } & \text { RAB } & \text { right abutment } \\ \mathrm{DS} & \text { downstream } & \text { RABUT } & \text { face of right abutment } \\ \mathrm{elev} & \text { elevation } & \text { RB } & \text { right bank } \\ \mathrm{f} / \mathrm{p} & \text { flood plain } & \text { ROB } & \text { right overbank } \\ \mathrm{ft}^{2} & \text { square feet } & \text { RWW } & \text { right wingwall } \\ \mathrm{ft} / \mathrm{ft} & \text { feet per foot } & \text { TH } & \text { town highway } \\ \mathrm{JCT} & \text { junction } & \text { UB } & \text { under bridge } \\ \mathrm{LAB} & \text { left abutment } & \text { US } & \text { upstream } \\ \mathrm{LABUT} & \text { face of left abutment } & \text { USGS } & \text { United States Geological Survey } \\ \mathrm{LB} & \text { left bank } & \text { VTAOT Vermont Agency of Transportation } \\ \mathrm{LOB} & \text { left overbank } & \text { WSPRO } & \text { water-surface profile model }\end{array}$

In this report, the words "right" and "left" refer to directions that would be reported by an observer facing downstream. Sea level: In this report, "sea level" refers to the National Geodetic Vertical Datum of 1929-- a geodetic datum derived from a general adjustment of the first-order level nets of the United States and Canada, formerly called Sea Level Datum of 1929.

In the appendices, the above abbreviations may be combined. For example, USLB would represent upstream left bank. 


\title{
LEVEL II SCOUR ANALYSIS FOR BRIDGE 34 (CORITH00500034) ON TOWN HIGHWAY 50, CROSSING THE SOUTH BRANCH WAITS RIVER, CORINTH, VERMONT
}

\author{
By Michael A. Ivanoff
}

\section{INTRODUCTION AND SUMMARY OF RESULTS}

This report provides the results of a detailed Level II analysis of scour potential at structure CORITH00500034 on Town Highway 50 crossing the South Branch Waits River, Corinth, Vermont (figures 1-8). A Level II study is a basic engineering analysis of the site, including a quantitative analysis of stream stability and scour (U.S. Department of Transportation, 1993). Results of a Level I scour investigation also are included in Appendix E of this report. A Level I investigation provides a qualitative geomorphic characterization of the study site. Information on the bridge, gleaned from Vermont Agency of Transportation (VTAOT) files, was compiled prior to conducting Level I and Level II analyses and is found in Appendix D.

The site is in the New England Upland section of the New England physiographic province in central Vermont. The $35.9-\mathrm{mi}^{2}$ drainage area is in a predominantly rural and forested basin. In the vicinity of the study site, the surface cover is pasture upstream and downstream of the bridge while the immediate banks have dense woody vegetation.

In the study area, the South Branch Waits River has an incised, meandering channel with a slope of approximately $0.005 \mathrm{ft} / \mathrm{ft}$, an average channel top width of $63 \mathrm{ft}$ and an average bank height of $6 \mathrm{ft}$. The channel bed material ranges from sand to cobble with a median grain size $\left(\mathrm{D}_{50}\right)$ of $23.7 \mathrm{~mm}(0.078 \mathrm{ft})$. The geomorphic assessment at the time of the Level I and Level II site visit on September 5, 1995, indicated that the reach was stable.

The Town Highway 50 crossing of the South Branch Waits River is a 56-ft-long, one-lane bridge consisting of one 54-foot steel thru-truss span (Vermont Agency of Transportation, written communication, March 24, 1995). The opening length of the structure parallel to the bridge face is $51.5 \mathrm{ft}$.The bridge is supported by vertical, concrete abutments with no wingwalls. Stone fill and bank material in front of the abutments create spill-through embankments. The channel is skewed approximately 30 degrees to the opening while the opening-skew-to-roadway is 15 degrees. 
A scour hole $2.5 \mathrm{ft}$ deeper than the mean thalweg depth was observed along the left bank through the bridge during the Level I assessment. The only scour protection measure at the site was type- 2 stone fill (less than 36 inches diameter) along the left and right banks extending from upstream to downstream through the bridge. The stone fill under the bridge creates spill-through embankments. Additional details describing conditions at the site are included in the Level II Summary and Appendices D and E.

Scour depths and recommended rock rip-rap sizes were computed using the general guidelines described in Hydraulic Engineering Circular 18 (Richardson and others, 1995) for the 100- and 500-year discharges. In addition, the incipient roadway-overtopping discharge was determined and analyzed as other potential worst-case scour scenario. Total scour at a highway crossing is comprised of three components: 1) long-term streambed degradation; 2) contraction scour (due to accelerated flow caused by a reduction in flow area at a bridge) and; 3 ) local scour (caused by accelerated flow around piers and abutments). Total scour is the sum of the three components. Equations are available to compute depths for contraction and local scour and a summary of the results of these computations follows.

Contraction scour for all modelled flows ranged from 0.0 to $3.0 \mathrm{ft}$. The worst-case contraction scour occurred at the incipient roadway-overtopping discharge, which was less than the 100-year discharge. Abutment scour ranged from 2.4 to $6.3 \mathrm{ft}$. The worst-case abutment scour occurred at the 500-year discharge. Additional information on scour depths and depths to armoring are included in the section titled "Scour Results". Scouredstreambed elevations, based on the calculated scour depths, are presented in tables 1 and 2. A cross-section of the scour computed at the bridge is presented in figure 8. Scour depths were calculated assuming an infinite depth of erosive material and a homogeneous particlesize distribution.

It is generally accepted that the Froehlich and HIRE equations (abutment scour) give "excessively conservative estimates of scour depths" (Richardson and others, 1995, p. 47). Usually, computed scour depths are evaluated in combination with other information including (but not limited to) historical performance during flood events, the geomorphic stability assessment, existing scour protection measures, and the results of the hydraulic analyses. Therefore, scour depths adopted by VTAOT may differ from the computed values documented herein. 


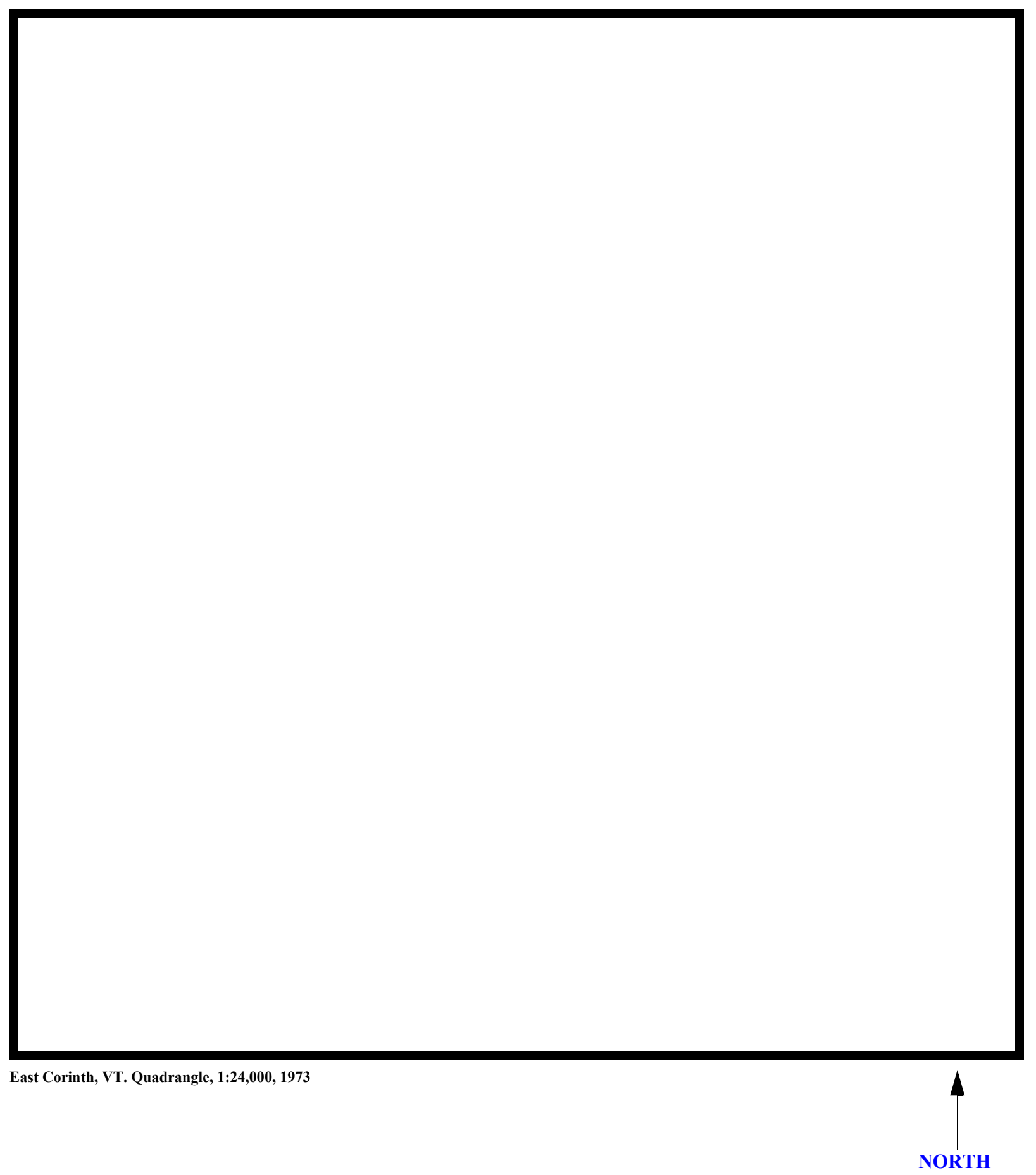

Figure 1. Location of study area on USGS 1:24,000 scale map. 
Figure 2. Location of study area on Vermont Agency of Transportation town highway map. 

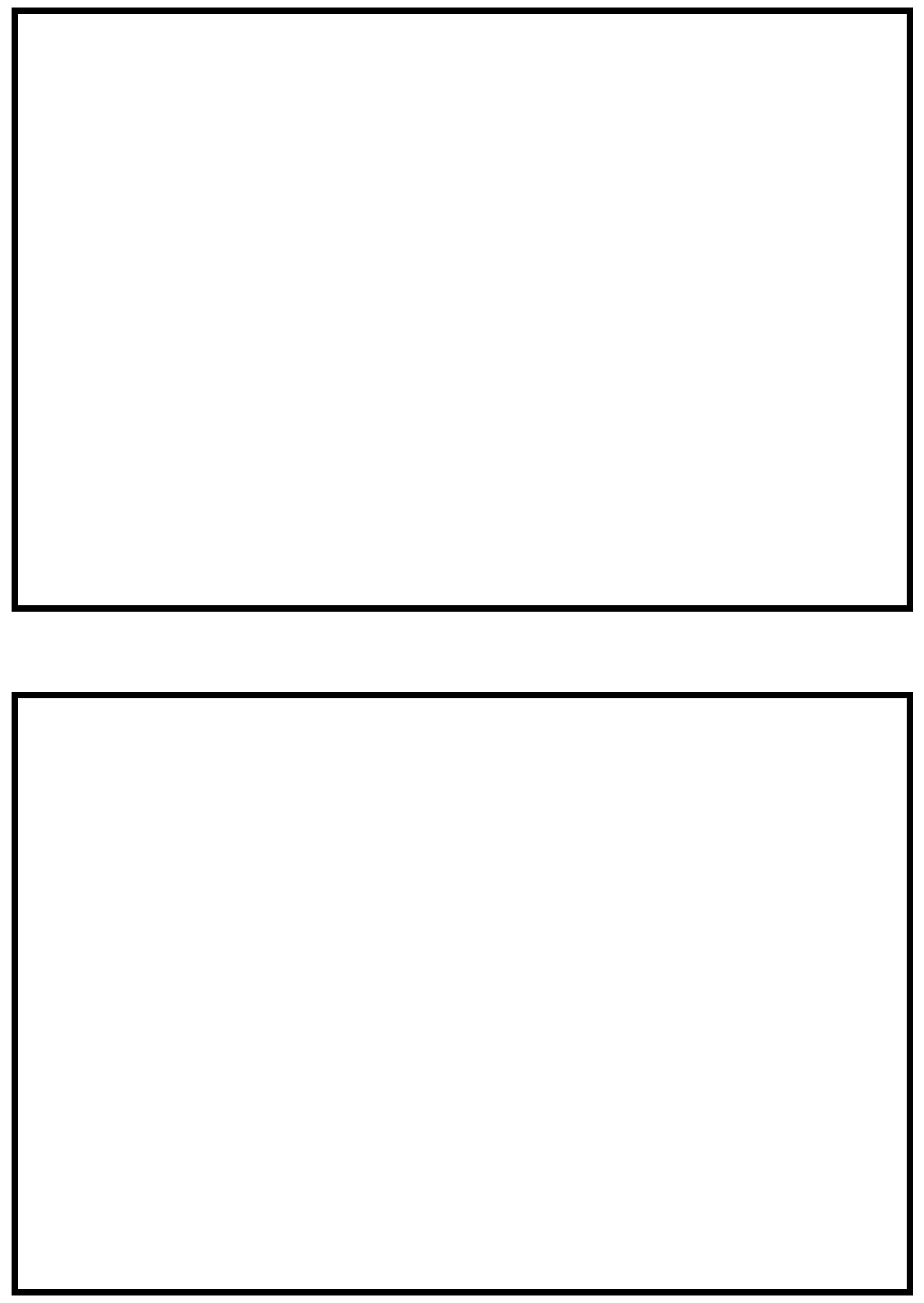

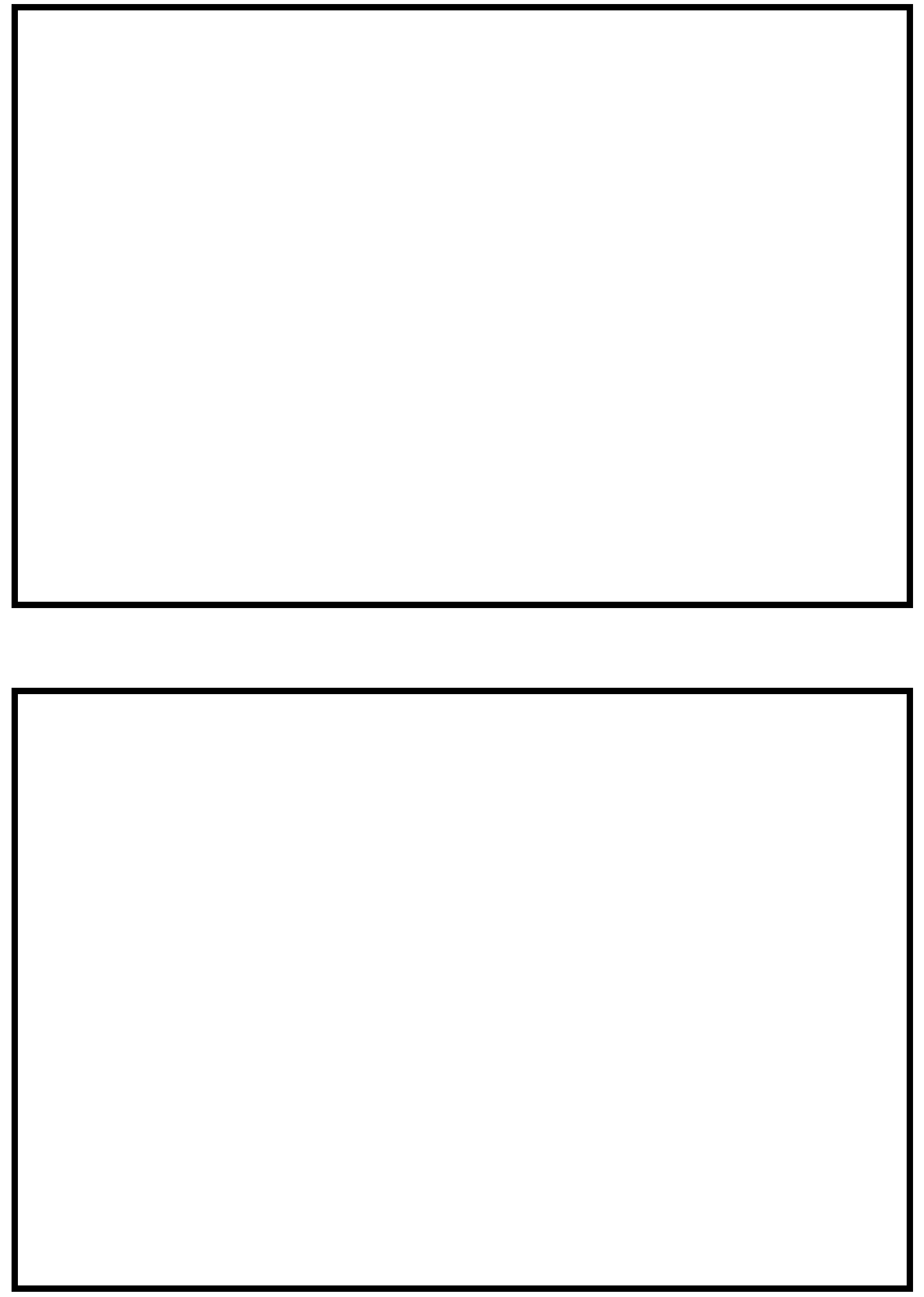


\section{LEVEL II SUMMARY}

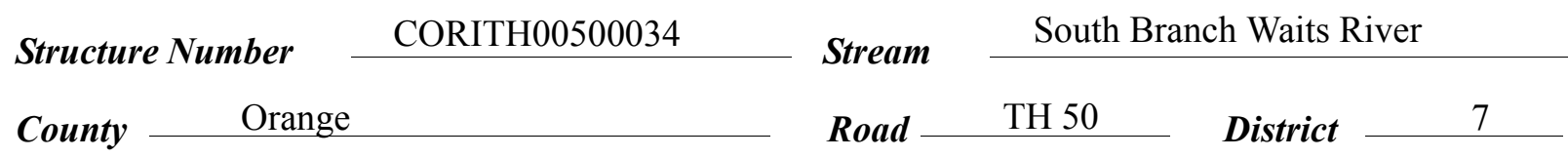

\section{Description of Bridge}

Bridge length $\frac{56}{4} \quad \boldsymbol{f t} \quad$ Bridge width $\frac{11.7}{f} \quad$ Max span length $\frac{54}{} \boldsymbol{f t}$ Alignment of bridge to road (on curve or straight) Abutment type Vertical, concrete

$\begin{array}{ll}\text { Stone fill on abutment? } & \text { Yes } \\ & \text { Type-2, along the left and right banks extending from upstream to }\end{array}$ Curve on right, Straight on left downstream through the bridge. Stone fill under the bridge creates spill-through embankments.

Abutments are concrete. There is a two and a half foot deep scour hole along the left bank through the bridge.

Yes

\section{0 \\ Yes}

Angle

Is bridge skewed to flood flow according to There ' survey?

Sloping

is a mild channel bend in the upstream reach. The scour hole has developed in the location, where the bend impacts the left bank.

Debris accumulation on bridge at time of Level I or Level II site visit:

$$
\begin{gathered}
\text { Date of incnortion } \\
\text { 9/5/95 } \\
\hline
\end{gathered}
$$

Level I

$$
9 / 5 / 95
$$

Moderate. There is some debris caught on boulders and trees are

Level II

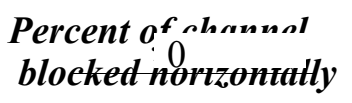

0
Percent of 0
blocked verticatty

0

leaning over the channel upstream.

Potential for debris

None noted as of 9/5/95.

Doscriho any, foaturos noar ar at tho hridos that mav, affoct flou, (includo ahsorvation dato) 


\section{Description of the Geomorphic Setting}

General topography The channel is located within a low relief valley with narrow flood plains. $9 / 5 / 95$

Geomorphic conditions at bridge site: downstream (DS), upstream (US)

Date of inspection Steep channel

DS left: $\quad$ bank to a narrow flood plain.

DS right: $\quad$ Steep channel bank to a narrow flood plain

US left: $\quad$ Steep channel bank to a narrow flood plain.

US right: $\quad$ Steep channel bank to a narrow flood plain.

\section{Description of the Channel}

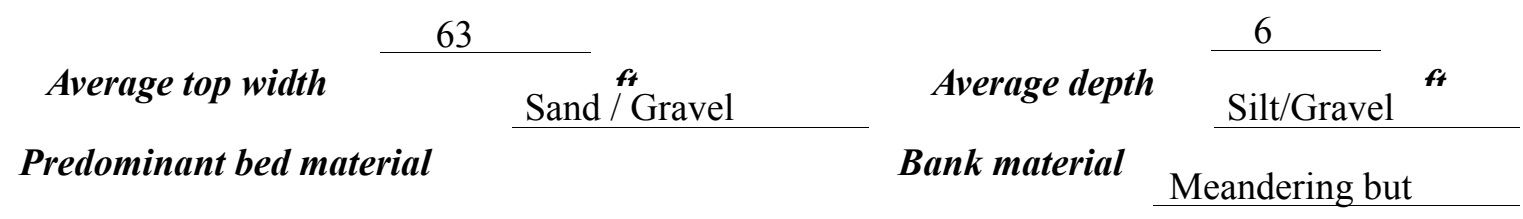

stable with semi-alluvial channel boundaries and narrow flood p̈lains.

Vegetative co 1 A few trees and brush with pasture on the flood plain.

DS left: $\quad$ A few trees and brush with pasture on the flood plain.

DS right: $\quad$ Trees and brush with pasture on the flood plain.

US left: $\quad$ Trees and brush with pasture on the flood plain.

US right: $\quad$ Yes

Do banks appear stable? -

date of observation.

None noted during the

assessment of 9/5/95.

Describe any obstructions in channel and date of observation. 


\title{
Hydrology
}

Drainage area $\stackrel{35.9}{\boldsymbol{m i}^{2}}$

Percentage of drainage area in physiographic provinces: (approximate)

Physiographic province/section New England/New England Upland
Percent of drainage area 100

\begin{abstract}
Is drainage area considered rural or urban?
Rural urbanization:

Describe any significant
\end{abstract}

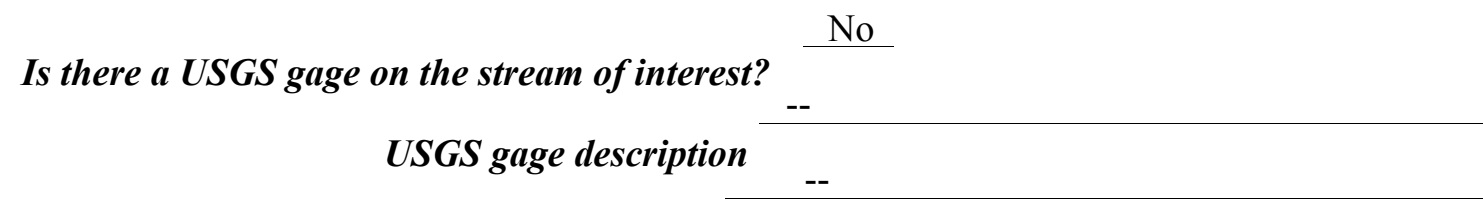

USGS gage number

Gage drainage area $\mathrm{mi}^{2}$

No

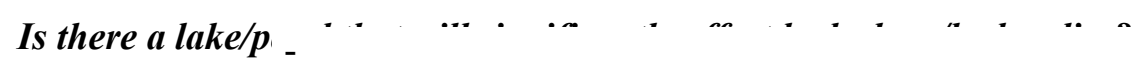

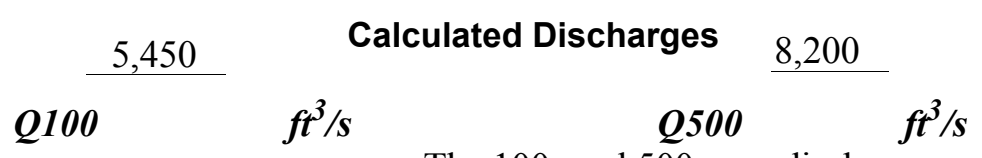

The 100- and 500-year discharges are based on a

drainage area relationship.[(35.9/16.2)exp 0.67] with bridge number 20 in Corinth. Bridge number 20 crosses Cooksville Brook a tributary to the South Branch Waits River upstream of this site and has flood frequency estimates available from the VTAOT database. The drainage area above bridge number 20 is 16.2 square miles. The drainage area adjusted discharge values are within a range defined by several empirical flood frequency curves (Benson, 1962; Johnson and Tasker, 1974; FHWA, 1983; Potter, 1957a\&b; Talbot, 1887). 


\section{Description of the Water-Surface Profile Model (WSPRO) Analysis}

Datum for WSPRO analysis (USGS survey, sea level, VTAOT plans)

USGS survey

Datum tie between USGS survey and VTAOT plans

None

Description of reference marks used to determine USGS datum. $\quad$ RM1 is a chiseled X on

top of the downstream end of the right abutment (elev. $502.62 \mathrm{ft}$, arbitrary survey datum). RM2

is a chiseled X on top of the downstream end of the left abutment (elev. $502.60 \mathrm{ft}$, arbitrary

survey datum). RM3 is a nail in the streamward post marking trail $25 \mathrm{~W}$ located $215 \mathrm{ft}$ bankward

from the right abutment along TH 50 and 215 feet along

the trail upstream (elev. $506.78 \mathrm{ft}$, arbitrary survey datum).

Crnce-Sertinnc Ilced in WSPRO Analvcic

\begin{tabular}{cccl}
\hline${ }^{1}$ Cross-section & $\begin{array}{c}\text { Section } \\
\text { Reference } \\
\text { Distance } \\
\text { (SRD) in feet }\end{array}$ & $\begin{array}{c}{ }^{2} \text { Cross-section } \\
\text { development }\end{array}$ & \multicolumn{1}{c}{ Comments } \\
\hline EXITX & -51 & 1 & Exit section \\
FULLV & 0 & 2 & $\begin{array}{l}\text { Downstream Full-valley } \\
\text { section (Templated from } \\
\text { EXITX) }\end{array}$ \\
BRIDG & 0 & 1 & $\begin{array}{l}\text { Bridge section } \\
\text { Road Grade section } \\
\text { RDWAY }\end{array}$ \\
APPRO & 10 & 1 & Approach section \\
\hline
\end{tabular}

${ }^{1}$ For location of cross-sections see plan-view sketch included with Level I field form, Appendix E.

For more detail on how cross-sections were developed see WSPRO input file.

2 Cross-section development: (1) survey at SRD, (2) shift of survey data to SRD, (3) modification of survey data,

(4) composite bridge section, (5) other. 


\section{Data and Assumptions Used in WSPRO Model}

Hydraulic analyses of the reach were done by use of the Federal Highway Administration's WSPRO step-backwater computer program (Shearman and others, 1986, and Shearman, 1990). The analyses reported herein reflect conditions existing at the site at the time of the study. Furthermore, in the development of the model it was necessary to assume no accumulation of debris or ice at the site. Results of the hydraulic model are presented in the Bridge Hydraulic Summary, Appendix B, and figure 7.

Channel roughness factors (Manning's " $n$ ") used in the hydraulic model were estimated using field inspections at each cross section following the general guidelines described by Arcement and Schneider (1989). Final adjustments to the values were made during the modelling of the reach. Channel " $n$ " values for the reach ranged from 0.030 to 0.046 , and overbank " $\mathrm{n}$ " values ranged from 0.030 to 0.032 .

Normal depth at the exit section (EXITX) was assumed as the starting water surface. This depth was computed by use of the slope-conveyance method outlined in the user's manual for WSPRO (Shearman, 1990). The slope used was $0.0048 \mathrm{ft} / \mathrm{ft}$, which was estimated from the topographic map (U.S. Geological Survey, 1973).

The approach section (APPRO) was surveyed one bridge length upstream of the upstream face as recommended by Shearman and others (1986). This location provides a consistent method for determining scour variables.

For the incipient-overtopping discharge, WSPRO assumes critical depth at the bridge section. A supercritical model was developed for this discharge. After analyzing both the supercritical and subcritical profiles for the discharge, it can be determined that the water surface profile does pass through critical depth within the bridge opening. Thus, the assumption of critical depth at the bridge is a satisfactory solution. 


\section{Bridge Hydraulics Summary}

\begin{tabular}{lll} 
Average bridge embankment elevation & 506.1 \\
\cline { 3 - 3 } Average low steel elevation & 502.7 & $\boldsymbol{f t}$
\end{tabular}

100-year discharge $\quad 5,450 \quad \mathrm{ft}^{3} / \mathrm{s}$

Water-surface elevation in bridge opening $\quad 502.7 \quad f t$

Road overtopping? ___ Yes Discharge over road _ $3,074,{ }^{3} / \mathrm{s}$

\begin{tabular}{llll} 
Area of flow in bridge opening & $358 \quad \mathrm{ft}^{2}$ & \\
\cline { 2 - 3 } Average velocity in bridge opening & 6.4 & $\mathrm{ft} / \mathrm{s}$
\end{tabular}

Maximum WSPRO tube velocity at bridge $\quad 8.0 \quad \mathrm{ft} / \mathrm{s}$

Water-surface elevation at Approach section with bridge 503.6

Water-surface elevation at Approach section without bridge $\quad 501.1$

Amount of backwater caused by bridge

$2.5 \quad i$

500-year discharge $\quad 8,200 \quad \mathrm{ft}^{3} / \mathrm{s}$

Water-surface elevation in bridge opening $\quad 502.7$ ft

Road overtopping? ___ Yes Discharge over road _ $5,440, \ldots / s$

$\begin{array}{llll}\text { Area of flow in bridge opening } & 358 \quad \boldsymbol{f t}^{2} & \\ \text { Average velocity in bridge opening } & & 7.8 \quad \mathrm{ft} / \mathrm{s}\end{array}$

Maximum WSPRO tube velocity at bridge 9.8 's

Water-surface elevation at Approach section with bridge 504.2

Water-surface elevation at Approach section without bridge $\quad 501.6$

Amount of backwater caused by bridge $\quad 2.6 . t$

Incipient overtopping discharge $\quad 1,830 \mathrm{ft}^{3} / \mathrm{s}$

Water-surface elevation in bridge opening $498.2 \quad t$

Area of flow in bridge opening $\quad 156 \quad \mathrm{ft}^{2}$

Average velocity in bridge opening $\quad 11.7 \quad \mathrm{ft} / \mathrm{s}$

Maximum WSPRO tube velocity at bridge $14.7 \quad \mathrm{ft} / \mathrm{s}$

Water-surface elevation at Approach section with bridge

Water-surface elevation at Approach section without bridge

Amount of backwater caused by bridge $\quad 2.3$ it

501.6

499.3 


\section{Scour Analysis Summary}

\section{Special Conditions or Assumptions Made in Scour Analysis}

Scour depths were computed using the general guidelines described in Hydraulic Engineering Circular 18 (Richardson and others, 1995). Scour depths were calculated assuming an infinite depth of erosive material and a homogeneous particle-size distribution. The results of the scour analysis are presented in tables 1 and 2 and a graph of the scour depths is presented in figure 8 .

Contraction scour for the incipient road-overtopping was computed by use of the Laursen clear-water contraction scour equation (Richardson and others, 1995, p. 32, equation 20). The 100-year and 500-year discharges resulted in unsubmerged orifice flow. Contraction scour at bridges with orifice flow is best estimated by use of the Chang pressureflow scour equation (oral communication, J. Sterling Jones, October 4, 1996). The computed streambed armoring depths suggest that armoring will not limit the depth of contraction scour.

For comparison, contraction scour for the discharges resulting in orifice flow was also computed by use of the Laursen clear-water contraction scour equation and the Umbrell pressure-flow equation (Richardson and others, 1995, p. 144) and presented in Appendix F. Furthermore, for those discharges resulting in unsubmerged orifice flow, contraction scour was computed by substituting estimates for the depth of flow at the downstream bridge face in the contraction scour equations. Results with respect to these substitutions are provided in Appendix F.

Abutment scour was computed by use of the HIRE equation (Richardson and others, 1995, p. 49, equation 29) because the HIRE equation is recommended when the length to depth ratio of the embankment blocking flow exceeds 25. Variables for the HIRE equation include the Froude number of the flow approaching the embankments, the length of the embankment blocking flow, and the depth of flow approaching the embankment less any roadway overtopping.

Because the influence of scour processes on the spill-through embankment material is uncertain, the scour depth at the vertical concrete abutment walls is unknown. Therefore, the total scour depths computed at the toe of each embankment were applied for the entire spill-through embankment as shown in figure 8. 


\section{Scour Results}

\section{0-yr discharge 500-yr discharge}

Contraction scour:

(Scour depths in feet)

Main channel

Live-bed scour

Clear-water scour

Depth to armoring

Left overbank

Right overbank

Local scour:

Abutment scour

Left abutment

5.7

6.3

4.1

Right abutment

Pier scour

Pier 1

4.0

5.2

2.4

Pier 2

Pier 3

\section{Abutments:}

Left abutment

Right abutment

Piers:

Pier 1

Pier 2

overtopping discharge 


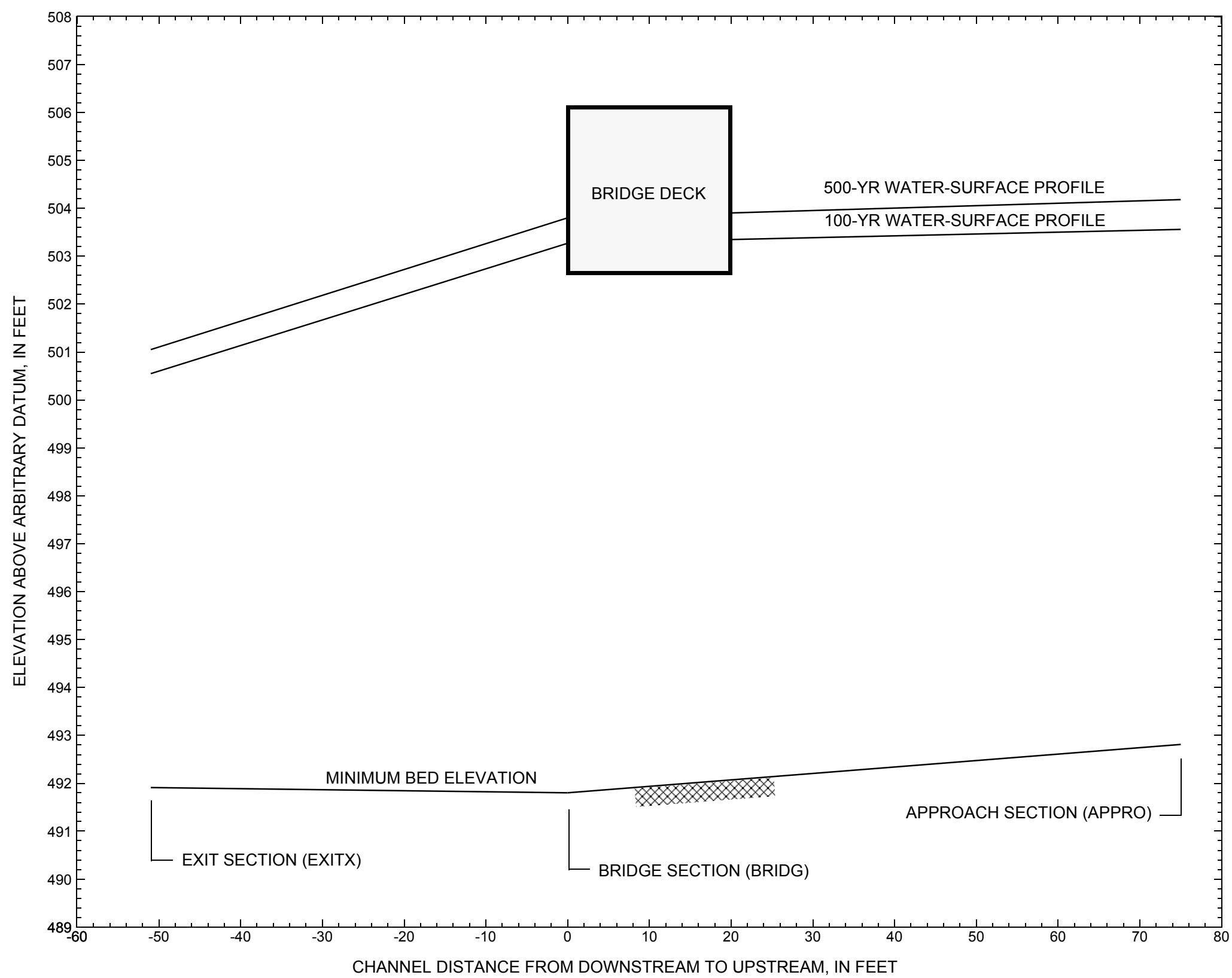

Figure 7. Water-surface profiles for the 100- and 500-yr discharges at structure CORITH00500034 on Town Highway 50, crossing the South Branch Waits River, Corinth, Vermont. 


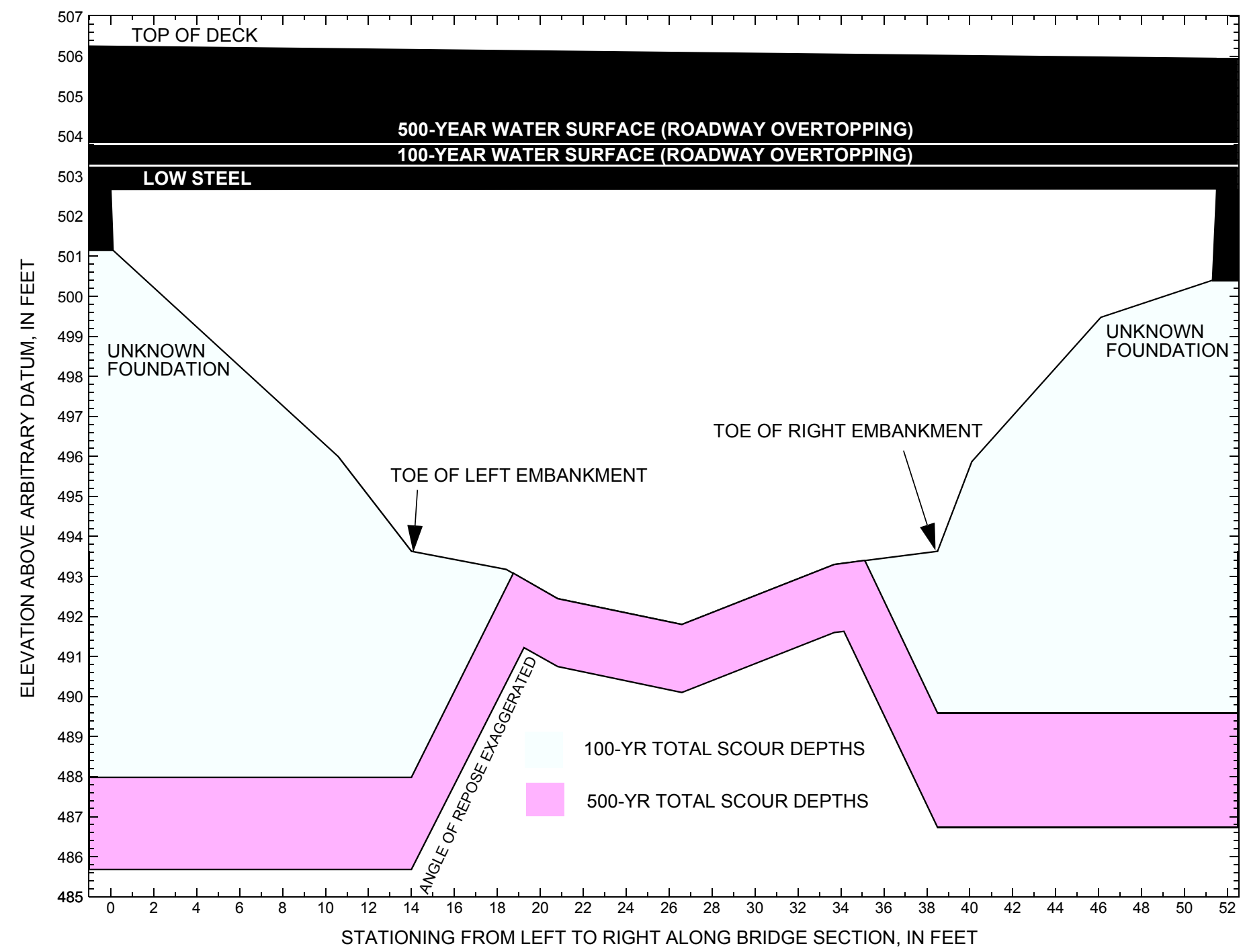

Figure 8. Scour elevations for the 100-yr and 500-yr discharges at structure CORITH00500034 on Town Highway 50, crossing the South Branch Waits River, Corinth, Vermont. 
Table 1. Remaining footing/pile depth at abutments for the 100-year discharge at structure CORITH00500034 on Town Highway 50, crossing the South Branch Waits River, Corinth, Vermont.

[VTAOT, Vermont Agency of Transportation; --,no data]

\begin{tabular}{|c|c|c|c|c|c|c|c|c|c|c|c|}
\hline Description & Station $^{1}$ & $\begin{array}{l}\text { VTAOT } \\
\text { minimum } \\
\text { low-chord } \\
\text { elevation } \\
\text { (feet) }\end{array}$ & $\begin{array}{c}\text { Surveyed } \\
\text { minimum } \\
\text { low-chord } \\
\text { elevation } \\
\text { (feet) }\end{array}$ & $\begin{array}{c}\text { Bottom of } \\
\text { footing/pile } \\
\text { elevation } \\
\text { (feet) }\end{array}$ & $\begin{array}{l}\text { Channel } \\
\text { elevation at } \\
\text { abutment/ } \\
\text { pier }^{2} \\
\text { (feet) }\end{array}$ & $\begin{array}{l}\text { Contraction } \\
\text { scour depth } \\
\text { (feet) }\end{array}$ & $\begin{array}{l}\text { Abutment } \\
\text { scour } \\
\text { depth } \\
\text { (feet) }\end{array}$ & $\begin{array}{l}\text { Pier } \\
\text { scour } \\
\text { depth } \\
\text { (feet) }\end{array}$ & $\begin{array}{l}\text { Depth of } \\
\text { total scour } \\
\text { (feet) }\end{array}$ & $\begin{array}{c}\text { Elevation of } \\
\text { scour }^{2} \\
\text { (feet) }\end{array}$ & $\begin{array}{c}\text { Remaining } \\
\text { footing/pile } \\
\text { depth } \\
\text { (feet) }\end{array}$ \\
\hline \multicolumn{12}{|c|}{100 -yr. discharge is 5,450 cubic-feet per second } \\
\hline Left abutment & 0.0 & -- & 502.7 & -- & 501.2 & 0.0 & -- & -- & -- & -- & -- \\
\hline $\begin{array}{c}\text { Toe of left } \\
\text { embankment }\end{array}$ & 14.0 & -- & -- & -- & 493.6 & 0.0 & 5.7 & -- & 5.7 & 487.9 & -- \\
\hline $\begin{array}{l}\text { Toe of right } \\
\text { embankment }\end{array}$ & 38.5 & -- & -- & -- & 493.6 & 0.0 & 4.0 & -- & 4.0 & 489.6 & -- \\
\hline Right abutment & 51.5 & -- & 502.7 & -- & 500.4 & 0.0 & -- & -- & -- & -- & -- \\
\hline
\end{tabular}

1.Measured along the face of the most constricting side of the bridge.

2.Arbitrary datum for this study.

Table 2. Remaining footing/pile depth at abutments for the 500-year discharge at structure CORITH00500034 on Town Highway 50, crossing the South Branch Waits River, Corinth, Vermont.

[VTAOT, Vermont Agency of Transportation; --, no data]

\begin{tabular}{|c|c|c|c|c|c|c|c|c|c|c|c|}
\hline Description & Station $^{1}$ & $\begin{array}{l}\text { VTAOT } \\
\text { minimum } \\
\text { low-chord } \\
\text { elevation } \\
\text { (feet) }\end{array}$ & $\begin{array}{l}\text { Surveyed } \\
\text { minimum } \\
\text { low-chord } \\
\text { elevation } \\
\text { (feet) }\end{array}$ & $\begin{array}{l}\text { Bottom of } \\
\text { footing/pile } \\
\text { elevation }{ }^{2} \\
\text { (feet) }\end{array}$ & $\begin{array}{c}\text { Channel } \\
\text { elevation at } \\
\text { abutment/ } \\
\text { pier }^{2} \\
\text { (feet) }\end{array}$ & $\begin{array}{l}\text { Contraction } \\
\text { scour depth } \\
\text { (feet) }\end{array}$ & $\begin{array}{l}\text { Abutment } \\
\text { scour } \\
\text { depth } \\
\text { (feet) }\end{array}$ & $\begin{array}{l}\text { Pier } \\
\text { scour } \\
\text { depth } \\
\text { (feet) }\end{array}$ & $\begin{array}{l}\text { Depth of } \\
\text { total scour } \\
\text { (feet) }\end{array}$ & $\begin{array}{c}\text { Elevation of } \\
\text { scour }^{2} \\
\text { (feet) }\end{array}$ & $\begin{array}{c}\text { Remaining } \\
\text { footing/pile } \\
\text { depth } \\
\text { (feet) }\end{array}$ \\
\hline \multicolumn{12}{|c|}{500 -yr. discharge is 8,200 cubic-feet per second } \\
\hline Left abutment & 0.0 & -- & 502.7 & -- & 501.2 & 1.7 & -- & -- & -- & -- & -- \\
\hline $\begin{array}{c}\text { Toe of left } \\
\text { embankment }\end{array}$ & 14.0 & -- & -- & -- & 493.6 & 1.7 & 6.3 & -- & 8.0 & 485.6 & -- \\
\hline $\begin{array}{l}\text { Toe of right } \\
\text { embankment }\end{array}$ & 38.5 & -- & -- & -- & 493.6 & 1.7 & 5.2 & -- & 6.9 & 486.7 & -- \\
\hline Right abutment & 51.5 & -- & 502.7 & -- & 500.4 & 1.7 & -- & -- & -- & -- & -- \\
\hline
\end{tabular}

1.Measured along the face of the most constricting side of the bridge.

2.Arbitrary datum for this study. 


\section{SELECTED REFERENCES}

Arcement, G.J., Jr., and Schneider, V.R., 1989, Guide for selecting Manning's roughness coefficients for natural channels and flood plains: U.S. Geological Survey Water-Supply Paper 2339, 38 p.

Barnes, H.H., Jr., 1967, Roughness characteristics of natural channels: U.S. Geological Survey Water-Supply Paper 1849,213 p.

Benson, M. A., 1962, Factors Influencing the Occurrence of Floods in a Humid Region of Diverse Terrain: U.S. Geological Survey WaterSupply Paper 1580-B, 64 p.

Brown, S.A. and Clyde, E.S., 1989, Design of riprap revetment: Federal Highway Administration Hydraulic Engineering Circular No. 11, Publication FHWA-IP-89-016, 156 p.

Federal Highway Administration, 1983, Runoff estimates for small watersheds and development of sound design: Federal Highway Administration Report FHWA-RD-77-158.

Federal Highway Administration, 1993, Stream Stability and Scour at Highway Bridges: Participant Workbook: Federal Highway Administration Report FHWA-HI-91-011.

Froehlich, D.C., 1989, Local scour at bridge abutments in Ports, M.A., ed., Hydraulic Engineering--Proceedings of the 1989 National Conference on Hydraulic Engineering: New York, American Society of Civil Engineers, p. 13-18.

Hayes, D.C.,1993, Site selection and collection of bridge-scour data in Delaware, Maryland, and Virginia: U.S. Geological Survey WaterResources Investigation Report 93-4017, 23 p.

Interagency Advisory Committee on Water Data, 1982, Guidelines for determining flood flow frequency: U.S. Geological Survey, Bulletin 17B of the Hydrology Subcommittee, 190 p.

Johnson, C.G. and Tasker, G.D.,1974, Progress report on flood magnitude and frequency of Vermont streams: U.S. Geological Survey OpenFile Report 74-130, 37 p.

Lagasse, P.F., Schall, J.D., Johnson, F., Richardson, E.V., Chang, F., 1995, Stream Stability at Highway Structures: Federal Highway Administration Hydraulic Engineering Circular No. 20, Publication FHWA-IP-90-014, 144 p.

Laursen, E.M., 1960, Scour at bridge crossings: Journal of the Hydraulics Division, American Society of Civil Engineers, v. 86, no. HY2, p. 39-53.

Potter, W. D., 1957a, Peak rates of runoff in the Adirondack, White Mountains, and Maine woods area, Bureau of Public Roads

Potter, W. D., 1957b, Peak rates of runoff in the New England Hill and Lowland area, Bureau of Public Roads

Richardson, E.V. and Davis, S.R., 1995, Evaluating scour at bridges: Federal Highway Administration Hydraulic Engineering Circular No. 18, Publication FHWA-IP-90-017, 204 p.

Richardson, E.V., Simons, D.B., and Julien, P.Y., 1990, Highways in the river environment: Federal Highway Administration Publication FHWA-HI-90-016.

Ritter, D.F., 1984, Process Geomorphology: W.C. Brown Co., Debuque, Iowa, 603 p.

Shearman, J.O., 1990, User's manual for WSPRO--a computer model for water surface profile computations: Federal Highway Administration Publication FHWA-IP-89-027, 187 p.

Shearman, J.O., Kirby, W.H., Schneider, V.R., and Flippo, H.N., 1986, Bridge waterways analysis model; research report: Federal Highway Administration Publication FHWA-RD-86-108, 112 p.

Talbot, A.N., 1887, The determination of water-way for bridges and culverts.

U.S. Department of Transportation, 1993, Stream stability and scour at highway bridges, Participant Workbook: Federal Highway Administration Publication FHWA HI-91-011.

U.S. Geological Survey, 1973, East Corinth, Vermont 7.5 Minute Series quadrangle map: U.S. Geological Survey Topographic Maps, Scale 1:24,000. 


\section{APPENDIX A: \\ WSPRO INPUT FILE}




\section{WSPRO INPUT FILE}

U.S. Geological Survey WSPRO Input File cori034.wsp Hydraulic analysis for structure CORITH00500034 Date: 06-AUG-97 Bridge 34 on Town Highway 50 over South Branch Waits River by MAI

$\begin{array}{lllllllllllllllllllll}6 & 29 & 30 & 552 & 553 & 551 & 5 & 16 & 17 & 13 & 3 & * & 15 & 14 & 23 & 21 & 11 & 12 & 4 & 7 & 3\end{array}$

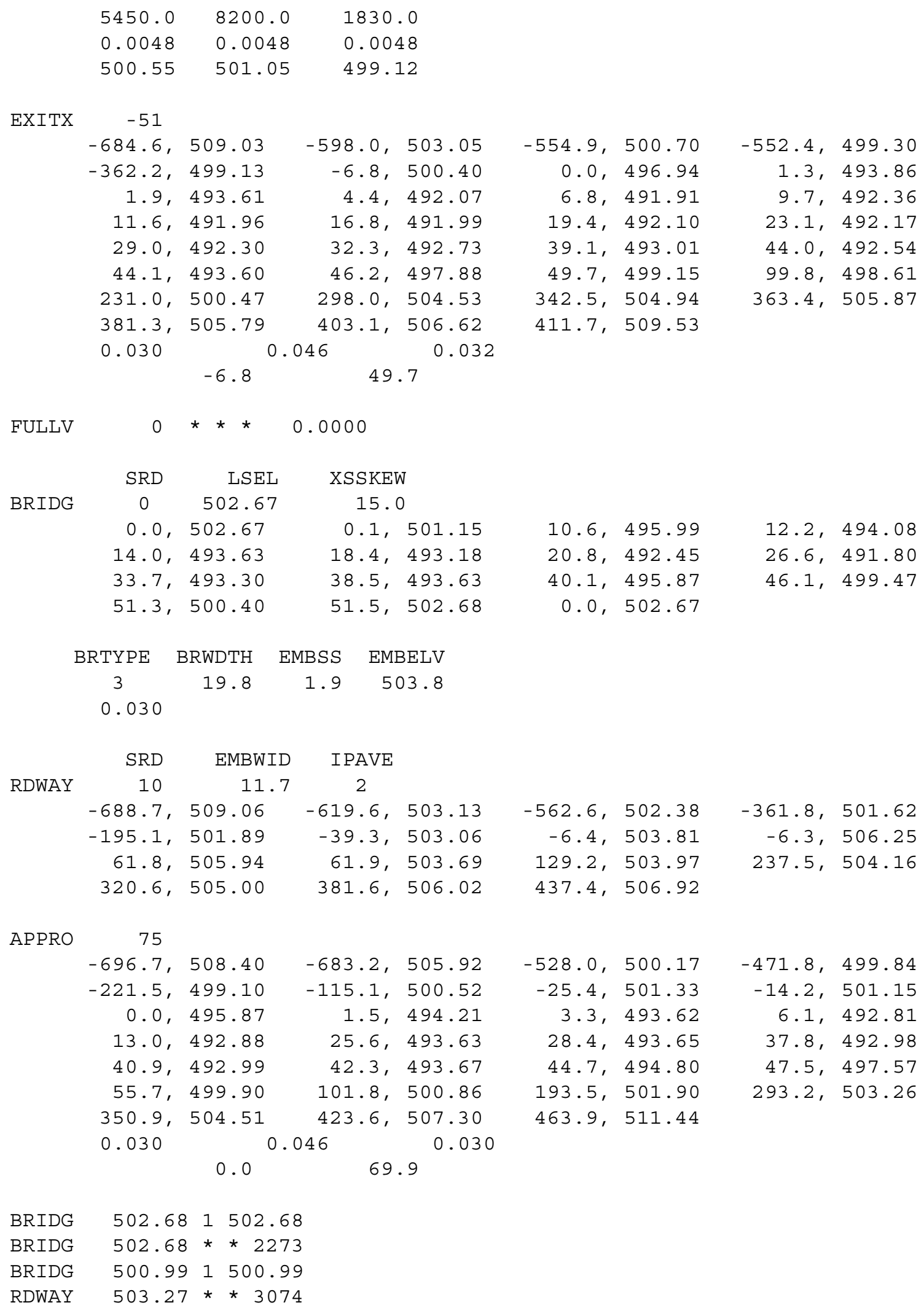


WSPRO INPUT FILE (continued)

\begin{tabular}{|c|c|c|c|c|}
\hline HP & 1 APPRO & 503.56 & 1 & 503.56 \\
\hline $\begin{array}{l}\text { HP } \\
\text { * }\end{array}$ & 2 APPRO & 503.56 & * & * 5450 \\
\hline HP & 1 BRIDG & 502.68 & 1 & 502.68 \\
\hline$P$ & 2 BRIDG & 502.68 & * & * 2790 \\
\hline$P$ & 1 BRIDG & 501.42 & 1 & 501.42 \\
\hline $\mathrm{HP}$ & 2 RDWAY & 503.80 & * & * 5440 \\
\hline $\mathrm{HP}$ & 1 APPRO & 504.18 & 1 & 504.18 \\
\hline $\begin{array}{l}\mathrm{HP} \\
\star\end{array}$ & 2 APPRO & 504.18 & * & * 8200 \\
\hline $\mathrm{HP}$ & 1 BRIDG & 498.24 & 1 & 498.24 \\
\hline $\mathrm{HP}$ & 2 BRIDG & 498.24 & $\star$ & * 1830 \\
\hline $\mathrm{HP}$ & 1 APPRO & 501.65 & 1 & 501.65 \\
\hline & 2 APPRO & 501.65 & * & * 1830 \\
\hline & & & & \\
\hline
\end{tabular}




\section{APPENDIX B: \\ WSPRO OUTPUT FILE}




\section{WSPRO OUTPUT FILE}

U.S. Geological Survey WSPRO Input File cori034.wsp

Hydraulic analysis for structure CORITH00500034 Date: 06-AUG-97

Bridge 34 on Town Highway 50 over South Branch Waits River by MAI *** RUN DATE \& TIME: 08-18-97 12:23

CROSS-SECTION PROPERTIES: ISEQ $=3 ;$ SECID $=$ BRIDG $; \quad$ SRD $=0$.

\begin{tabular}{|c|c|c|c|c|c|c|c|c|c|}
\hline \multirow[t]{2}{*}{ WSEL } & SA\# & AREA & $\mathrm{K}$ & TOPW & WETP & ALPH & LEW & REW & QCR \\
\hline & 1 & 358 & 39489 & 0 & 108 & & & & 19645822 \\
\hline 502.68 & & 358 & 39489 & 0 & 108 & 1.00 & 0 & 52 & 19645822 \\
\hline
\end{tabular}

$\begin{array}{rrrrrrr}\text { WSEL } & \text { LEW } & \text { REW } & \text { AREA } & \text { K } & Q & \text { VEL } \\ 502.68 & 0.0 & 51.5 & 357.6 & 39489 . & 2273 . & 6.36\end{array}$

\begin{tabular}{|c|c|c|c|c|c|c|c|c|c|c|c|}
\hline \multirow[t]{3}{*}{$\mathrm{x}$} & STA. & 0.0 & & \multicolumn{2}{|c|}{8.7} & \multicolumn{2}{|l|}{12.1} & 14.2 & \multicolumn{2}{|l|}{16.1} & \multirow[t]{3}{*}{17.9} \\
\hline & $A(I)$ & & 30.4 & & 22.3 & & 17.7 & 17.0 & & 16.0 & \\
\hline & $V(I)$ & & 3.74 & & 5.10 & & 6.43 & 6.68 & & 7.09 & \\
\hline \multirow[t]{3}{*}{$\mathrm{X}$} & STA. & 17.9 & & 19.5 & & 21.1 & & 22.6 & 24.0 & & 25.4 \\
\hline & $A(I)$ & & 15.5 & & 15.1 & & 14.7 & 14.2 & & 14.5 & \\
\hline & $\mathrm{V}(\mathrm{I})$ & & 7.34 & & 7.55 & & 7.74 & 7.98 & & 7.86 & \\
\hline \multirow[t]{3}{*}{$\mathrm{X}$} & STA. & 25.4 & & 26.7 & & 28.1 & & 29.6 & 31.1 & & 32.8 \\
\hline & $A(I)$ & & 14.3 & & 14.6 & & 14.6 & 14.9 & & 15.9 & \\
\hline & $V(I)$ & & 7.97 & & 7.81 & & 7.79 & 7.63 & & 7.16 & \\
\hline \multirow{7}{*}{$\mathrm{x}$} & STA. & 32.8 & & 34.6 & & 36.5 & & 38.5 & 41.9 & & 51.5 \\
\hline & $A(I)$ & & 16.0 & & 17.1 & & 18.1 & 22.8 & & 32.1 & \\
\hline & $V(I)$ & & 7.10 & & 6.66 & & 6.27 & 4.99 & & 3.54 & \\
\hline & CROSS - & SECTION & PROPERT & TIES : & ISEQ & $3 ;$ & SECID & $=$ BRIDG; & SRD & $=$ & 0 . \\
\hline & WSEL & SA\# & AREA & & $\mathrm{K}$ & TOPW & WETP & ALPH & LEW & REW & QCR \\
\hline & & 1 & 274 & & 9920 & 49 & 55 & & & & 3670 \\
\hline & 500.99 & & 274 & & 9920 & 49 & 55 & 1.00 & 0 & 51 & 3670 \\
\hline
\end{tabular}

VELOCITY DISTRIBUTION: ISEQ $=4 ;$ SECID $=$ RDWAY $; \quad$ SRD $=10$.

\begin{tabular}{|c|c|c|c|c|c|c|c|c|c|c|c|}
\hline & & SEL & LEW & REW & $\mathrm{ARE}$ & EA & K & Q & VEL & & \\
\hline & 503 & .27 & 1.2 & -30.1 & 661. & .9 & 35443 . & 3074 . & 4.64 & & \\
\hline & STA. & -621.2 & & -541.0 & & 504.2 & -474 & .6 & -449.2 & & -426.7 \\
\hline & $A(I)$ & & 49.6 & & 38.4 & & 34.5 & 32.3 & & 30.7 & \\
\hline & $V(I)$ & & 3.10 & & 4.01 & & 4.46 & 4.75 & & 5.01 & \\
\hline $\mathrm{x}$ & STA. & -426.7 & & -406.1 & & 387.5 & -369 & .8 & -352.9 & & .336 .1 \\
\hline & $A(I)$ & & 29.6 & & 28.2 & & 28.1 & 27.7 & & 27.4 & \\
\hline & $V(I)$ & & 5.19 & & 5.44 & & 5.48 & 5.55 & & 5.61 & \\
\hline $\mathrm{X}$ & STA. & -336.1 & & -318.8 & & 301.0 & -282 & .7 & -263.3 & & 243.0 \\
\hline & $A(I)$ & & 27.5 & & 27.9 & & 28.2 & 29.1 & & 30.0 & \\
\hline & $V(I)$ & & 5.59 & & 5.52 & & 5.45 & 5.28 & & 5.12 & \\
\hline X & STA. & -243.0 & & -221.5 & & 199.0 & -172 & .9 & -135.3 & & -30.1 \\
\hline & $A(I)$ & & 30.9 & & 31.6 & & 34.2 & 40.4 & & 55.7 & \\
\hline & $V(I)$ & & 4.97 & & 4.87 & & 4.49 & 3.81 & & 2.76 & \\
\hline & CROSS- & SECTION & PROPEF & RTIES : & ISEQ & 5 ; & SECID & $=A P P R O ;$ & SRD & $=$ & 75. \\
\hline & WSEL & SA\# & AREA & & $\mathrm{K}$ & TOPW & WETP & ALPH & LEW & REW & QCR \\
\hline & & 1 & 2112 & 23 & 7282 & 620 & 621 & & & & 22123 \\
\hline & & 2 & 567 & & 2085 & 70 & 73 & & & & 9152 \\
\hline & & 3 & 396 & & 7729 & 237 & 237 & & & & 2908 \\
\hline & 503.56 & & 3075 & 33 & 7096 & 927 & 930 & 1.06 & -619 & 307 & 30857 \\
\hline
\end{tabular}

VELOCITY DISTRIBUTION: ISEQ $=5 ; \quad$ SECID $=$ APPRO $; \quad$ SRD $=75$. $\begin{array}{lllll}\text { WSEL LEW REW AREA } & K & Q & \text { VEL }\end{array}$ 


\section{WSPRO OUTPUT FILE (continued)}

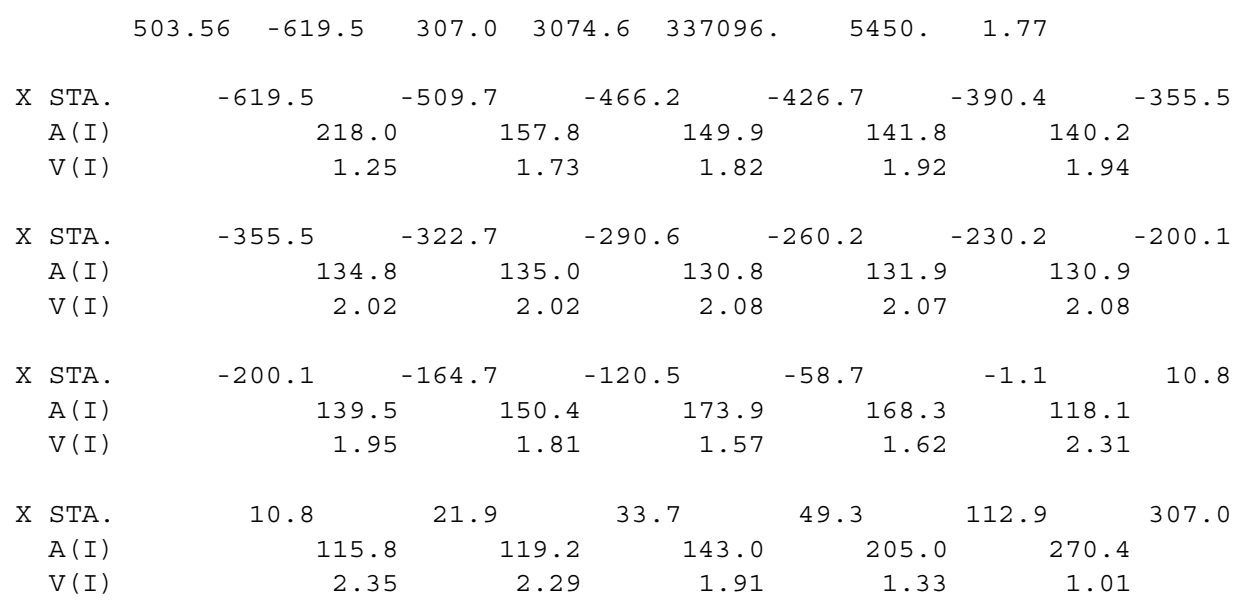

U.S. Geological Survey WSPRO Input File cori034.wsp

Hydraulic analysis for structure CORITH00500034 Date: 06-AUG-97 Bridge 34 on Town Highway 50 over South Branch waits River by MAI *** RUN DATE \& TIME: 08-18-97 12:23 CROSS-SECTION PROPERTIES: ISEQ = $3 ;$ SECID = BRIDG; $\mathrm{SRD}=0$.

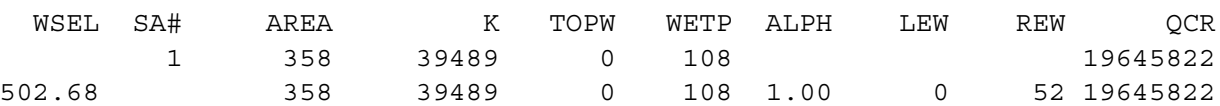
VELOCITY DISTRIBUTION: ISEQ $=3 ;$ SECID $=$ BRIDG; $\quad$ SRD $=0$.

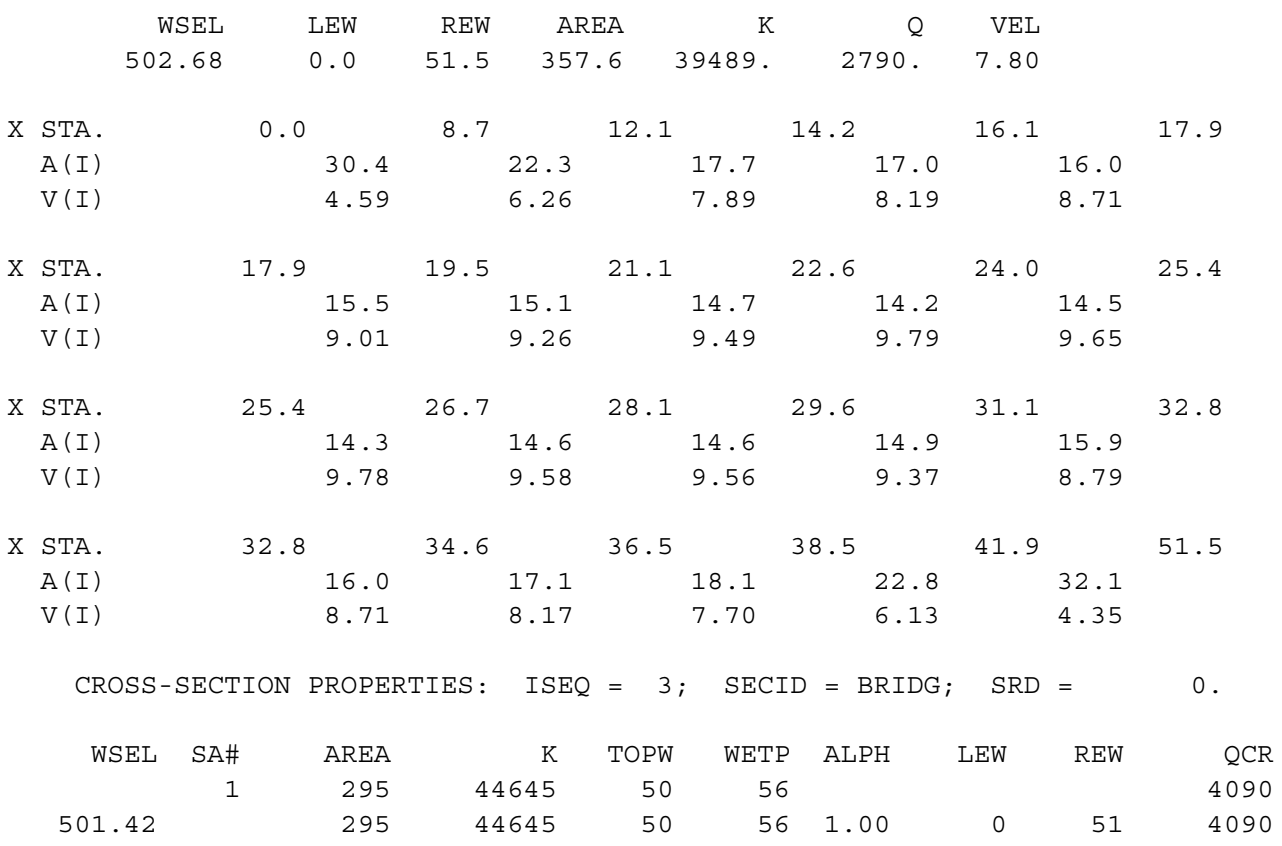

VELOCITY DISTRIBUTION: ISEQ = 4; SECID = RDWAY; SRD = 10.

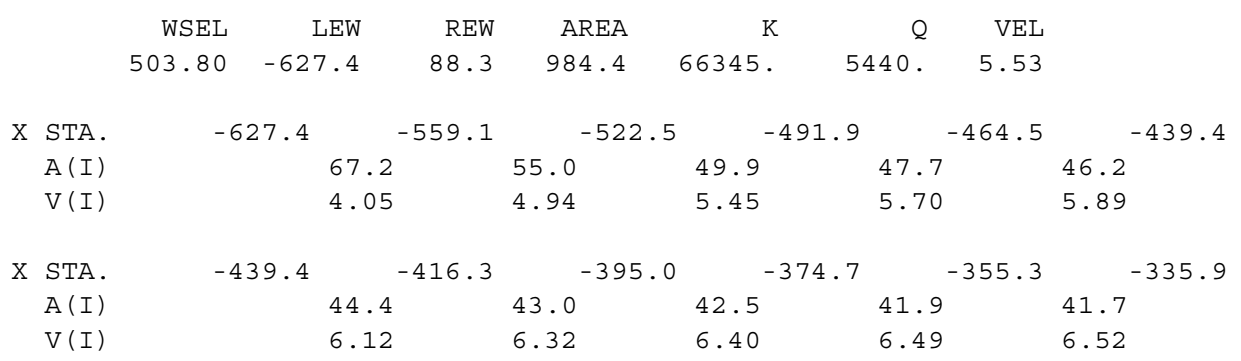


WSPRO OUTPUT FILE (continued)

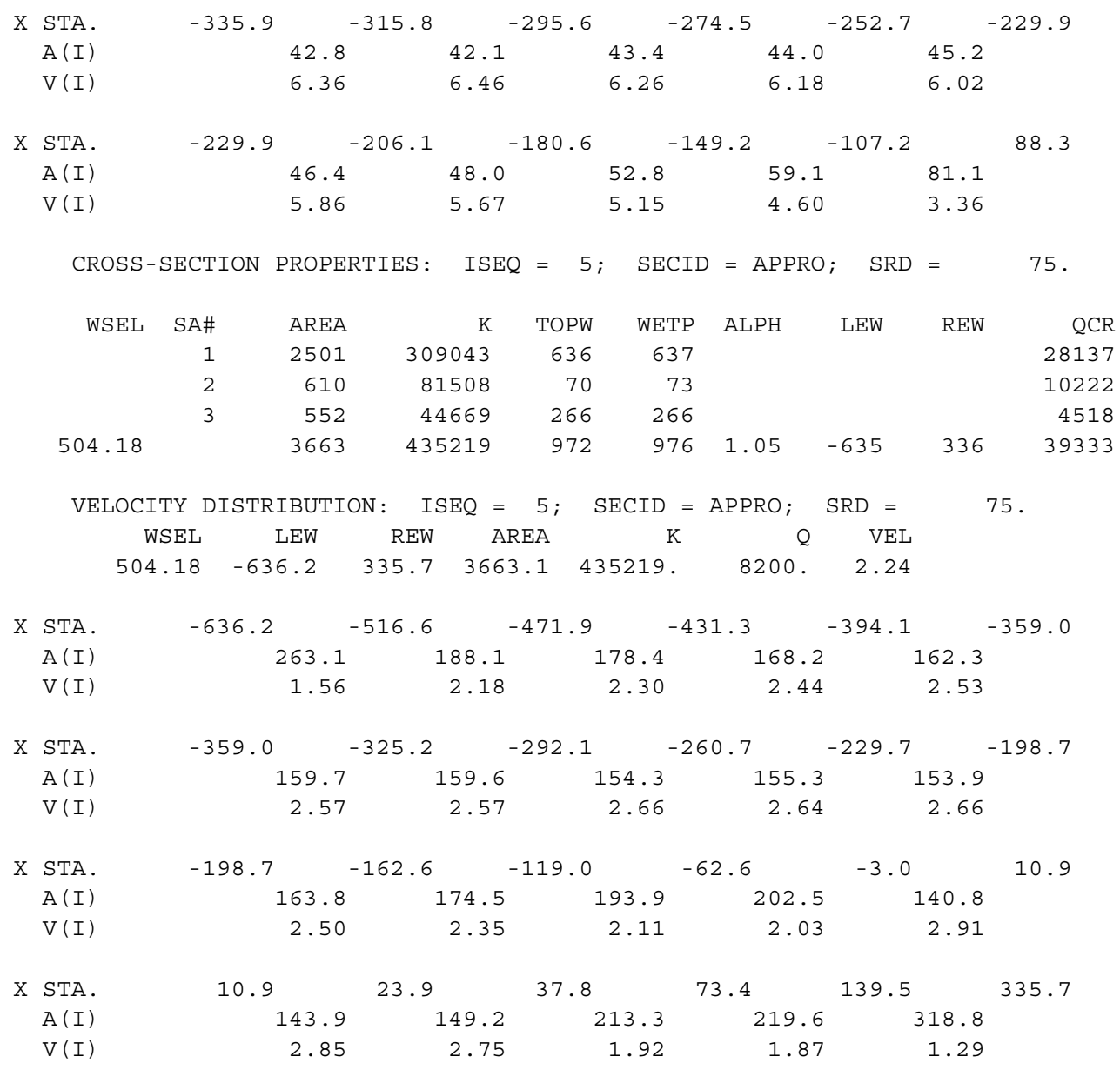

U.S. Geological Survey WSPRO Input File cori034.wsp

Hydraulic analysis for structure CORITH00500034 Date: 06-AUG-97 Bridge 34 on Town Highway 50 over South Branch Waits River by MAI

*** RUN DATE \& TIME: 09-08-97 09:11

\begin{tabular}{|c|c|c|c|c|c|c|c|c|c|c|c|c|}
\hline & CROSS-SEC & CTION & PROPERTI & IES: & ISEQ & $=$ & SEC & ID & $=$ BRIDG & SRD & $=$ & 0 . \\
\hline & WSEL & A\# & AREA & & $\mathrm{K}$ & TO & WET & & ALPH & LEW & REW & QCR \\
\hline & & 1 & 156 & & 9060 & & 7 & 0 & & & & 1824 \\
\hline & 498.24 & & 156 & & 9060 & & 7 & 0 & 1.00 & 6 & 44 & 1824 \\
\hline & VELOCITY & DISTF & RIBUTION : & & $\mathrm{SEQ}=$ & $3 ;$ & SECID & $=\mathrm{B}$ & BRIDG ; & $\mathrm{SRD}=$ & & 0 . \\
\hline & WSEL & & LEW & REW & AR & & K & & $Q$ & VEL & & \\
\hline & 498.24 & & 6.0 & 44.0 & 156 & 0 & 19060. & & 1830. & 11.73 & & \\
\hline $\mathrm{X}$ & STA. & 6. & & 13.2 & & 15 & & & 7.0 & 18.6 & & 20.0 \\
\hline & $A(I)$ & & 14.0 & & 9.2 & & 8.1 & & 7.6 & & 7.3 & \\
\hline & $V(I)$ & & 6.52 & & 9.89 & & 11.36 & & 12.06 & & 12.53 & \\
\hline $\mathrm{X}$ & STA. & 20. & & 21.2 & & 22 & & & 3.5 & 24.5 & & 25.6 \\
\hline & $A(I)$ & & 6.7 & & 6.6 & & 6.4 & & 6.3 & & 6.2 & \\
\hline & $V(I)$ & & 13.61 & & 13.90 & & 14.32 & & 14.48 & & 14.66 & \\
\hline $\mathrm{X}$ & STA. & 25.6 & & 26.6 & & 27 & & & 8.7 & 29.8 & & 31.1 \\
\hline & $A(I)$ & & 6.3 & & 6.2 & & 6.3 & & 6.6 & & 6.8 & \\
\hline & $V(I)$ & & 14.61 & & 14.71 & & 14.54 & & 13.81 & & 13.48 & \\
\hline X & STA. & 31.1 & & 32.4 & & 34 & & & 5.6 & 37.6 & & 44.0 \\
\hline & $A(I)$ & & 7.1 & & 7.5 & & 7.8 & & 9.1 & & 13.9 & \\
\hline
\end{tabular}




\section{WSPRO OUTPUT FILE (continued)}

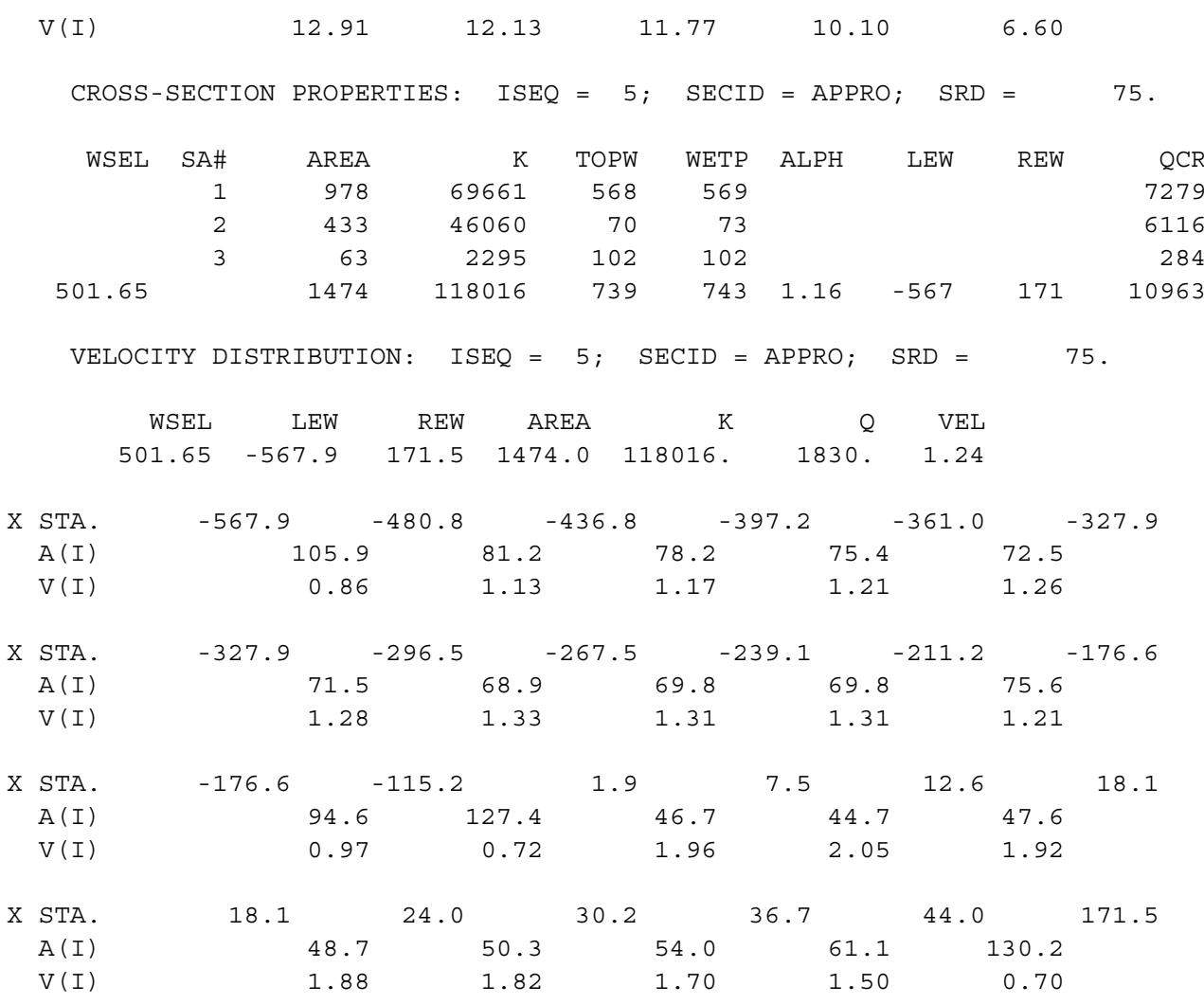

U.S. Geological Survey WSPRO Input File cori034.wsp

Hydraulic analysis for structure CORITH00500034 Date: 06-AUG-97 Bridge 34 on Town Highway 50 over South Branch waits River by MAI ** RUN DATE \& TIME: 08-18-97 12:23

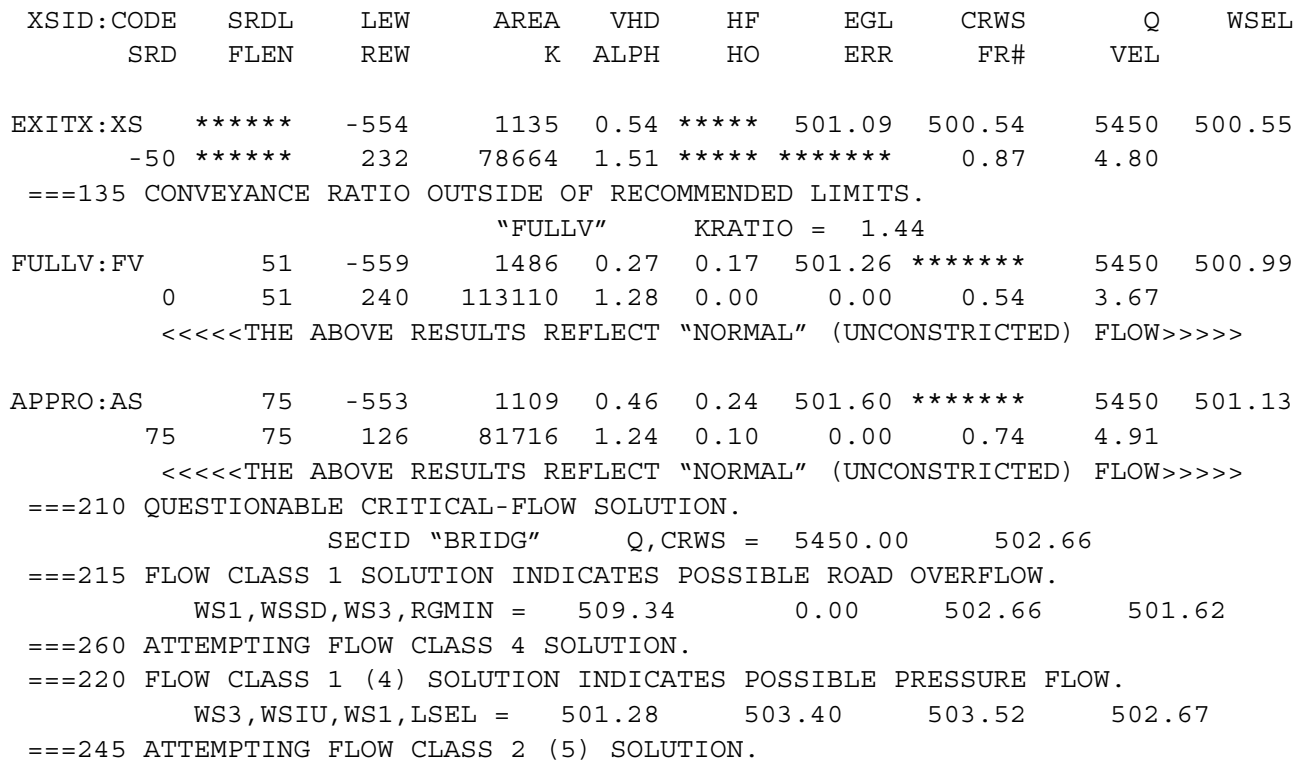


WSPRO OUTPUT FILE (continued)

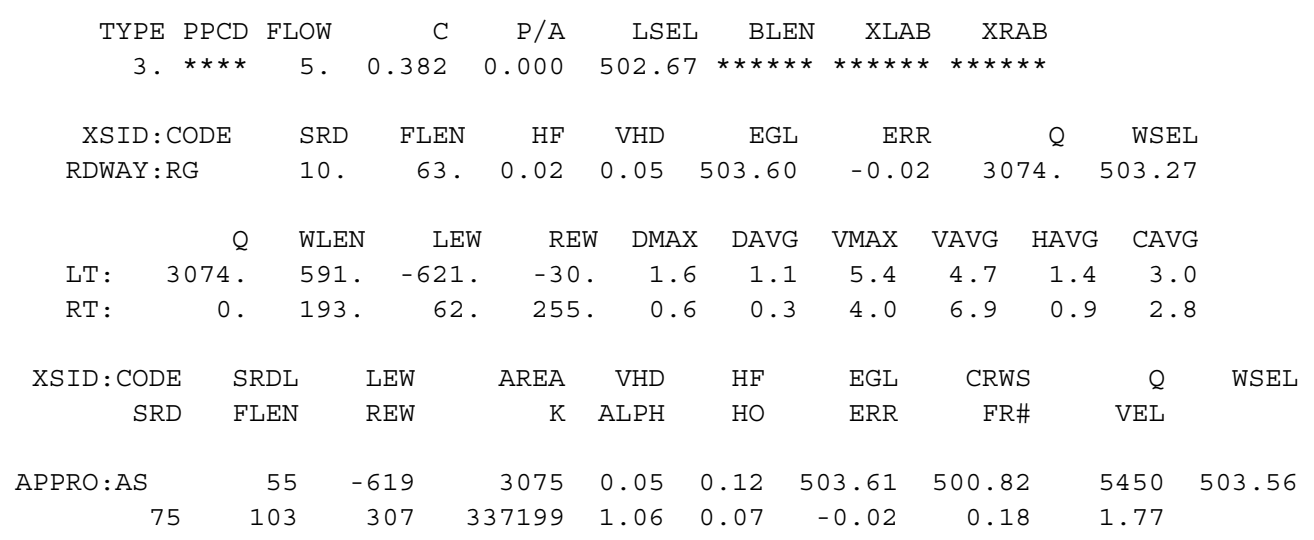

FIRST USER DEFINED TABLE.

$\begin{array}{lrrrrrrrr}\text { XSID : CODE } & \text { SRD } & \text { LEW } & \text { REW } & Q & \mathrm{~K} & \text { AREA } & \text { VEL } & \text { WSEL } \\ \text { EXITX : XS } & -51 . & -555 . & 232 . & 5450 . & 78664 . & 1135 . & 4.80 & 500.55 \\ \text { FULLV : FV } & 0 . & -560 . & 240 . & 5450 . & 113110 . & 1486 . & 3.67 & 500.99 \\ \text { BRIDG : BR } & 0 . & 0 . & 52 . & 2273 . & 39489 . & 358 . & 6.36 & 502.68 \\ \text { RDWAY : RG } & 10 . * * * * * * & 3074 . & 3074 . * * * * * * * * & 0 . & 2.00 & 503.27 \\ \text { APPRO : AS } & 75 . & -620 . & 307 . & 5450 . & 337199 . & 3075 . & 1.77 & 503.56\end{array}$

SECOND USER DEFINED TABLE.

$\begin{array}{lcrrrrrrrr}\text { XSID : CODE } & \text { CRWS } & \text { FR\# } & \text { YMIN } & \text { YMAX } & \text { HF } & \text { HO } & \text { VHD } & \text { EGL } & \text { WSEL } \\ \text { EXITX:XS } & 500.54 & 0.87 & 491.91 & 509.53 * * * * * * * * * * & 0.54 & 501.09 & 500.55 \\ \text { FULLV:FV } & * * * * * * * * & 0.54 & 491.91 & 509.53 & 0.17 & 0.00 & 0.27 & 501.26 & 500.99 \\ \text { BRIDG :BR } & 499.01 & 0.43 & 491.80 & 502.68 * * * * * * * * * * & 0.63 & 503.31 & 502.68 \\ \text { RDWAY : RG } & * * * * * * * * * * * * * * * & 501.62 & 509.06 & 0.02 * * * * * * & 0.05 & 503.60 & 503.27 \\ \text { APPRO:AS } & 500.82 & 0.18 & 492.81 & 511.44 & 0.12 & 0.07 & 0.05 & 503.61 & 503.56\end{array}$

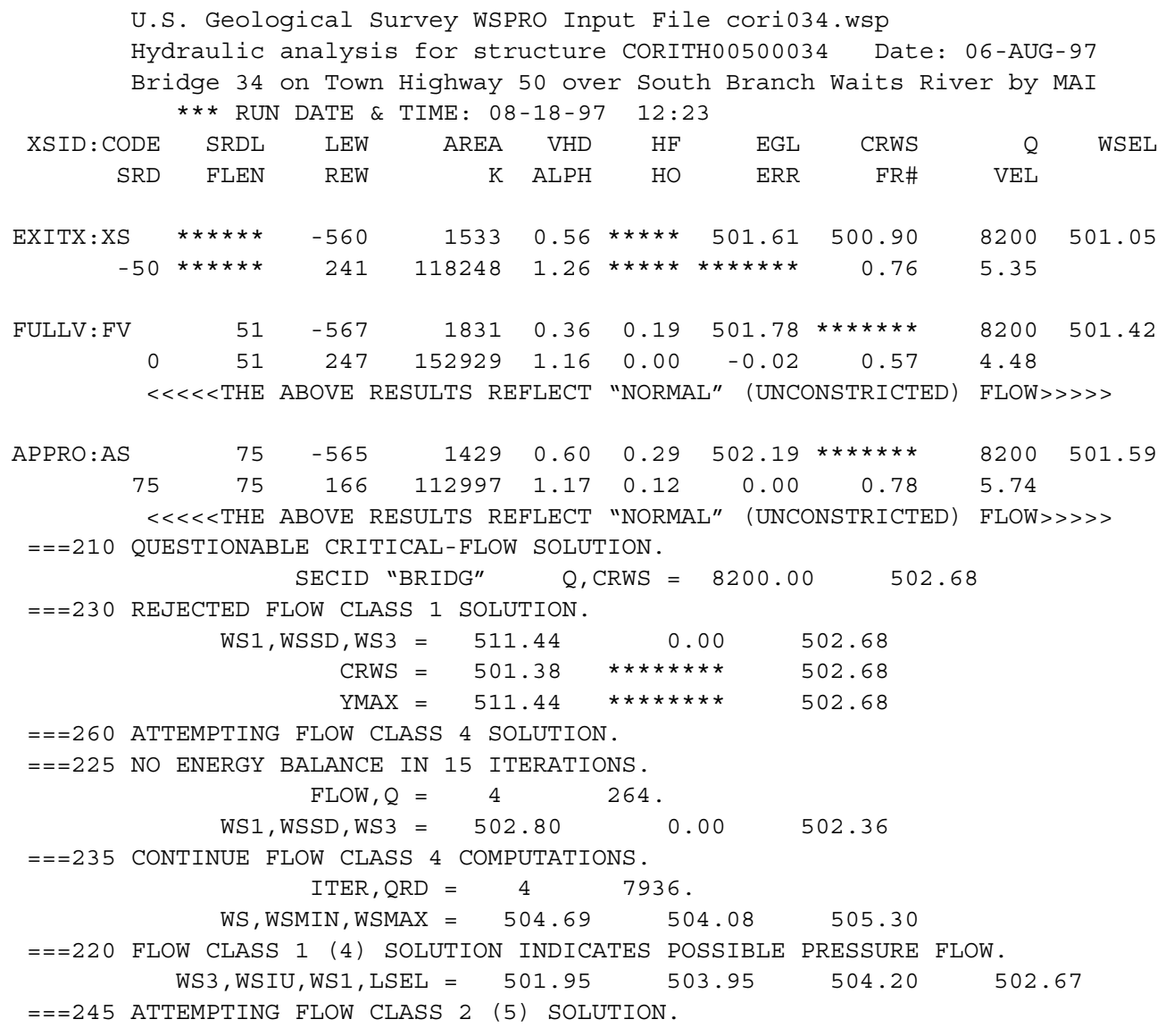




\section{WSPRO OUTPUT FILE (continued)}

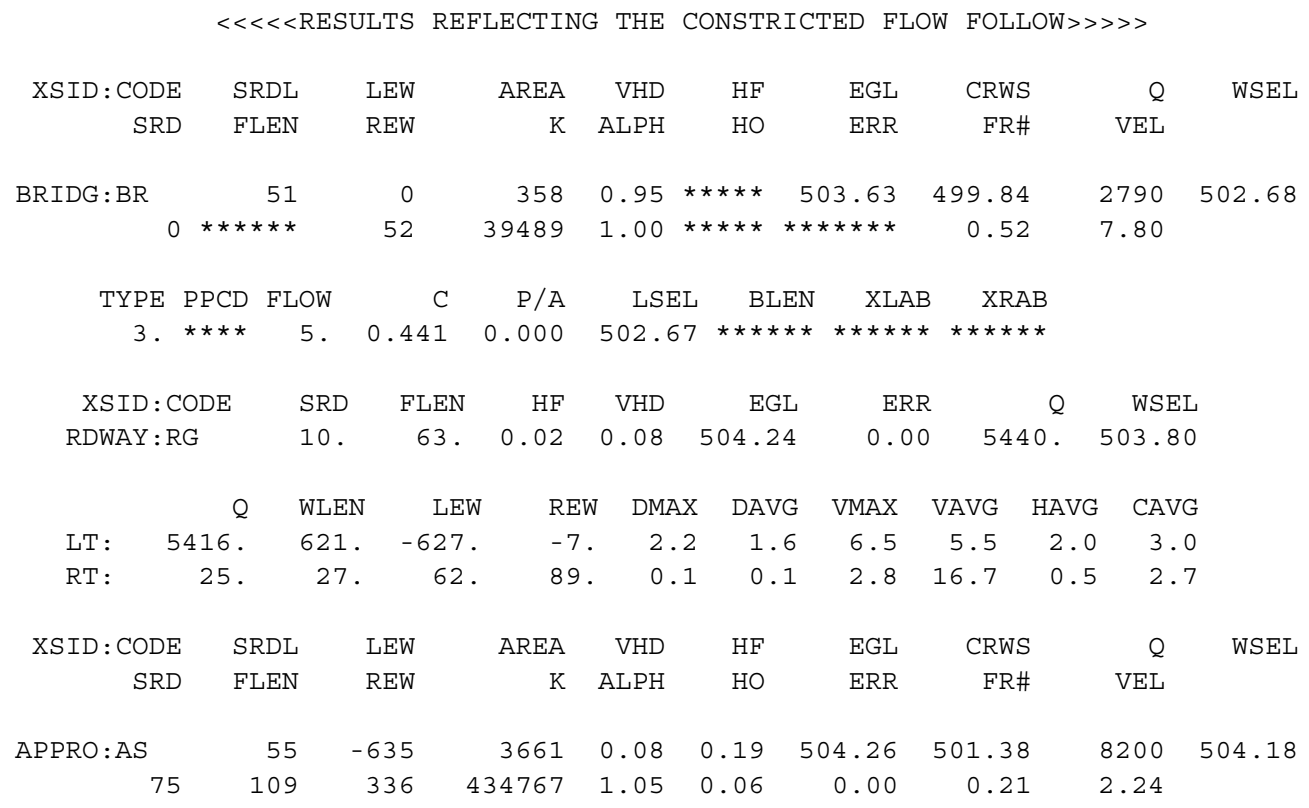

FIRST USER DEFINED TABLE.

$\begin{array}{lrrrrrrrr}\text { XSID : CODE } & \text { SRD } & \text { LEW } & \text { REW } & Q & \text { K } & \text { AREA } & \text { VEL } & \text { WSEL } \\ \text { EXITX : XS } & -51 . & -561 . & 241 . & 8200 . & 118248 . & 1533 . & 5.35 & 501.05 \\ \text { FULLV : FV } & 0 . & -568 . & 247 . & 8200 . & 152929 . & 1831 . & 4.48 & 501.42 \\ \text { BRIDG : BR } & 0 . & 0 . & 52 . & 2790 . & 39489 . & 358 . & 7.80 & 502.68 \\ \text { RDWAY : RG } & 10 . * * * * * * & 5416 . & 5440 . * * * * * * * * & 0 . & 2.00 & 503.80 \\ \text { APPRO : AS } & 75 . & -636 . & 336 . & 8200 . & 434767 . & 3661 . & 2.24 & 504.18\end{array}$

SECOND USER DEFINED TABLE.

$\begin{array}{lcrrrrrrrr}\text { XSID : CODE } & \text { CRWS } & \text { FR\# } & \text { YMIN } & \text { YMAX } & \text { HF } & \text { HO } & \text { VHD } & \text { EGL } & \text { WSEL } \\ \text { EXITX:XS } & 500.90 & 0.76 & 491.91 & 509.53 * * * * * * * * * * & 0.56 & 501.61 & 501.05 \\ \text { FULLV:FV } & * * * * * * * * & 0.57 & 491.91 & 509.53 & 0.19 & 0.00 & 0.36 & 501.78 & 501.42 \\ \text { BRIDG:BR } & 499.84 & 0.52 & 491.80 & 502.68 * * * * * * * * * * & 0.95 & 503.63 & 502.68 \\ \text { RDWAY:RG } & * * * * * * * * * * * * * * * & 501.62 & 509.06 & 0.02 * * * * * * & 0.08 & 504.24 & 503.80 \\ \text { APPRO:AS } & 501.38 & 0.21 & 492.81 & 511.44 & 0.19 & 0.06 & 0.08 & 504.26 & 504.18\end{array}$

U.S. Geological Survey WSPRO Input File corio34.wsp Hydraulic analysis for structure CORITH00500034 Date: 06-AUG-97 Bridge 34 on Town Highway 50 over South Branch waits River by MAI *** RUN DATE \& TIME: 08-18-97 12:23

\begin{tabular}{|c|c|c|c|c|c|c|c|c|c|}
\hline XSID : CODE & SRDL & LEW & AREA & VHD & $\mathrm{HF}$ & EGL & CRWS & $Q$ & WSEL \\
\hline SRD & FLEN & REW & $\mathrm{K}$ & $A L P H$ & $\mathrm{HO}$ & ERR & FR\# & VEL & \\
\hline EXITX:XS & 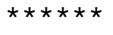 & -2 & 286 & 0.64 & $\star \star \star \star \star *$ & 499.36 & 496.25 & 1830 & 498.72 \\
\hline-50 & $\star \star \star \star \star * *$ & 107 & 26410 & 1.01 & $\star \star \star \star \star *$ & $\star \star \star \star \star \star \star \star *$ & 0.56 & 6.40 & \\
\hline FULLV: FV & 51 & -3 & 318 & 0.56 & 0.22 & 499.60 & $\star \star \star \star * * * *$ & 1830 & 499.04 \\
\hline 0 & 51 & 130 & 28839 & 1.08 & 0.00 & 0.02 & 0.66 & 5.76 & \\
\hline$<$ & $<<\mathrm{THE}$ & OVE $\mathrm{F}$ & JLTS R & ELECT & "NORMz & ( UNCC & (NSTRICTED) & FLOW & >>> \\
\hline
\end{tabular}

$==125$ FR\# EXCEEDS FNTEST AT SECID "APPRO": TRIALS CONTINUED. FNTEST, FR\#, WSEL, CRWS $=\begin{array}{llll}0.80 & 0.81 & 499.35 & 497.12\end{array}$

$===110$ WSEL NOT FOUND AT SECID "APPRO": REDUCED DELTAY.

$$
\text { WSLIM1, WSLIM2, DELTAY }=498.54 \quad 511.44 \quad 0.50
$$

$===115$ WSEL NOT FOUND AT SECID "APPRO": USED WSMIN = CRWS.

$$
\text { WSLIM1, WSLIM2, CRWS }=498.54 \quad 511.44 \quad 497.12
$$


WSPRO OUTPUT FILE (continued)

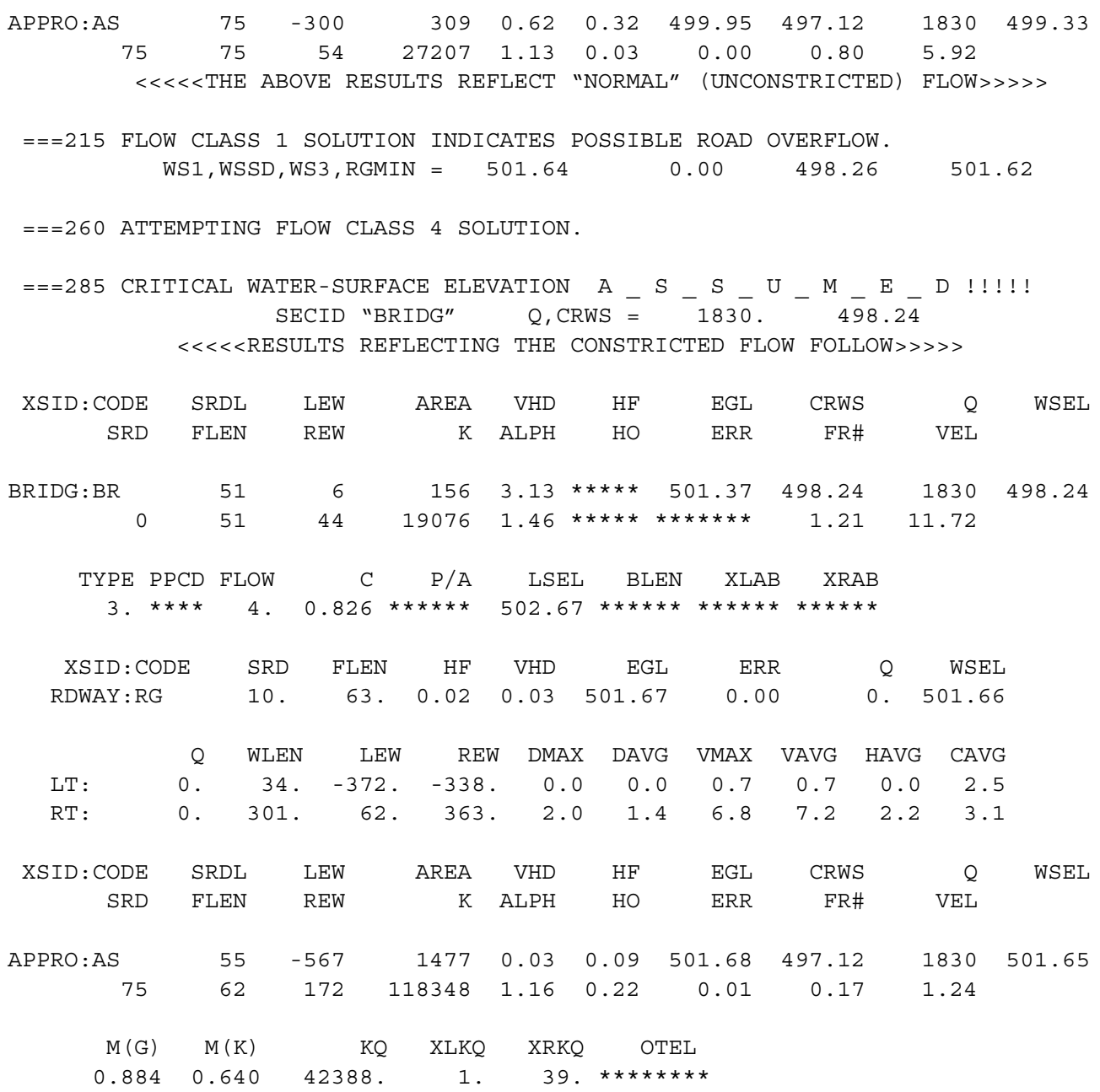

FIRST USER DEFINED TABLE.

\begin{tabular}{|c|c|c|c|c|c|c|c|c|}
\hline XSID: CODE & SRD & LEW & REW & $Q$ & $\mathrm{~K}$ & AREA & VEL & WSEL \\
\hline EXITX:XS & -51. & -3 & 107. & 1830. & 26410 . & 286 & 6.40 & 498.72 \\
\hline FULLV : FV & 0 & -4 & 130. & 1830. & 28839 . & 318. & 5.76 & 499.04 \\
\hline BRIDG : BR & 0. & 6. & 44. & 1830. & 19076. & 156. & 11.72 & 498.24 \\
\hline RDWAY : RG & $10 . *$ & 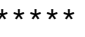 & 0 . & 0. & 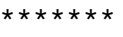 & 0 . & 2.00 & 501.66 \\
\hline APPRO : AS & 75. & -568. & 172 . & 1830 . & 118348. & 1477. & 1.24 & 501.65 \\
\hline
\end{tabular}

SECOND USER DEFINED TABLE.

\begin{tabular}{|c|c|c|c|c|c|c|c|c|}
\hline XSID : CODE & CRWS & FR\# & YMIN & YMAX & $\mathrm{HF}$ & VHD & EGL & WSEL \\
\hline EXITX:XS & 496.25 & 0.56 & 491.91 & $509.53 *$ & 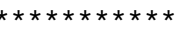 & 0.64 & 499.36 & 498.72 \\
\hline FULLV : FV & 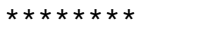 & 0.66 & 491.91 & 509.53 & 0.22 & 0.56 & 499.60 & 499.04 \\
\hline BRIDG : BR & 498.24 & 1.21 & 491.80 & $502.68 *$ & 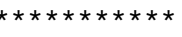 & 3.13 & 501.37 & 498.24 \\
\hline RDWAY : RG & 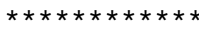 & 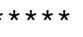 & 501.62 & 509.06 & $0.02 * * * * * *$ & 0.03 & 501.67 & 501.66 \\
\hline APPRO : AS & 497.12 & 0.17 & 492.81 & 511.44 & 0.09 & 0.03 & 501.68 & 501.65 \\
\hline
\end{tabular}




\section{APPENDIX C:}

\section{BED-MATERIAL PARTICLE-SIZE DISTRIBUTION}




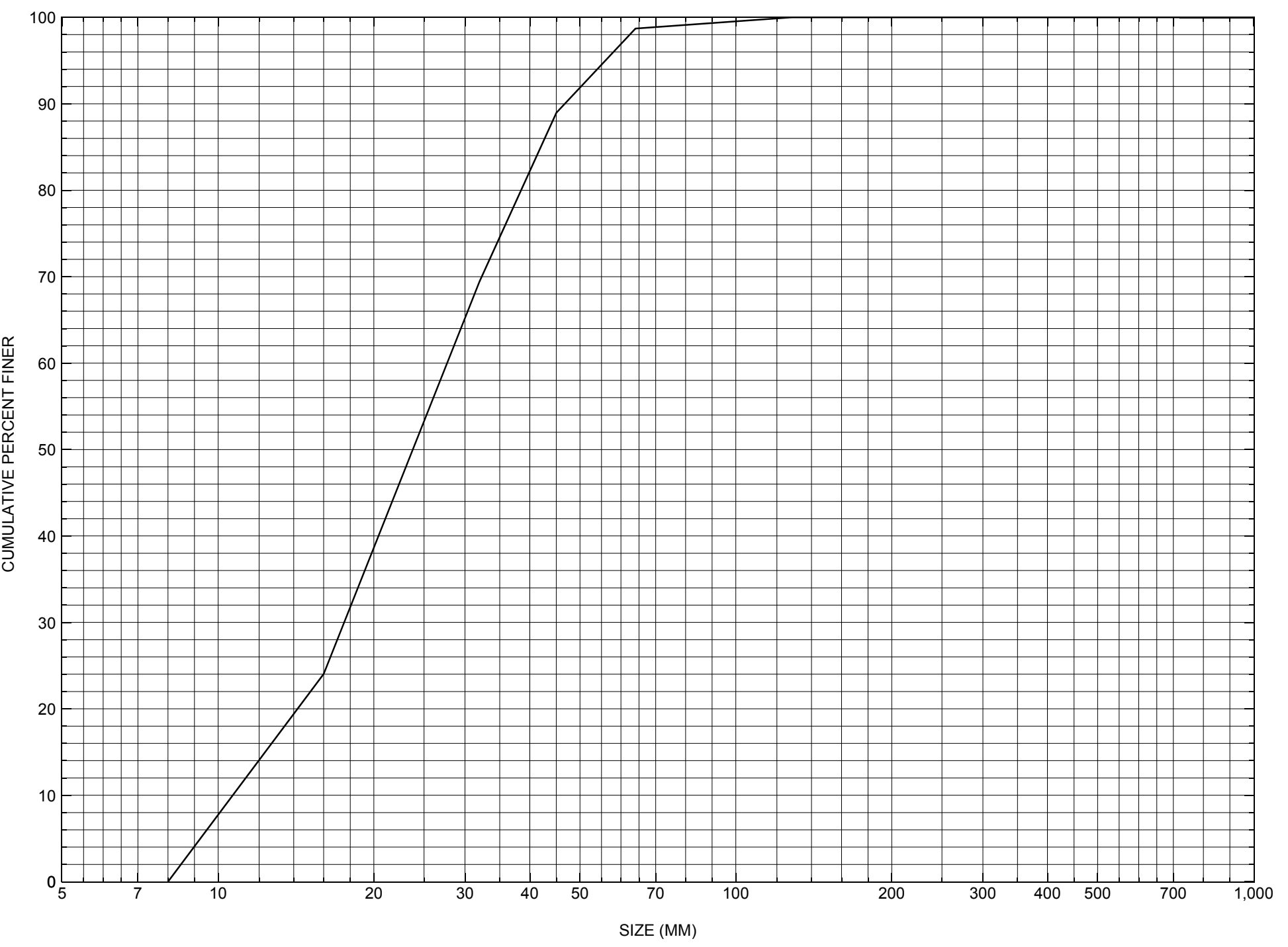

Appendix C. Bed material particle-size distribution for a pebble count in the channel approach of structure CORITH00500034, in Corinth, Vermont. 


\section{APPENDIX D: \\ HISTORICAL DATA FORM}




\section{Structure Number CORITH00500034}

\section{General Location Descriptive}

Data collected by (First Initial, Full last name) $\underline{\mathbf{E}}$. BOEHMLER

Date $(M M / D D / Y Y) \_\mathbf{0 3} / \underline{24} / \underline{95}$

Highway District Number (I - 2; nn) $\mathbf{0 7}$

Town (FIPS place code; I - 4; nnnnn) $\mathbf{1 5 7 0 0}$

Waterway (I - 6) SOUTH BRANCH WAITS RIVER

Route Number $\underline{\text { TH050 }}$

Topographic Map East Corinth

Latitude (I - 16; nnnn.n) $\mathbf{4 4 0 0 5}$
County (FIPS county code; I - 3; nnn)

Mile marker (I - 11; nnn.nnn) $\mathbf{0 0 0 0 0 0}$

Road Name (I - 7): -

Vicinity (I - 9) 0.1 MI JCT TH $50+$ TH 2

Hydrologic Unit Code: $\mathbf{0 1 0 8 0 1 0 3}$

Longitude (i - 17; nnnnn.n) $\mathbf{7 2 1 4 5}$

\section{Select Federal Inventory Codes}

FHWA Structure Number (I - 8) 10090500340905

Maintenance responsibility $(I-21 ; n n) \quad \mathbf{0 3}$

Year built (I - 27; YYYY) 1954

Average daily traffic, ADT (I - 29; nnnnnn) $\underline{\mathbf{0 0 0 0 5 0}}$

Year of ADT (I - 30; YY) $\mathbf{9 1}$

Opening skew to Roadway $(I-34 ; n n) \quad 15$

Operational status $(I-41 ; X) \underline{\mathbf{E}}$

Structure type (I- 43; nnn) $\mathbf{3 1 0}$

Approach span structure type $(I-44 ; n n n)$ 000

Number of spans (I - 45; nnn) $\underline{\mathbf{0 0 1}}$

Number of approach spans (I - 46; nnnn) $\mathbf{0 0 0 0}$

Comments:

The structural inspection report of $6 / 29 / 93$ indicates the structure is a steel thru-truss type bridge with a timber deck. The abutments are the spill-through type (earth embankments protected with some boulders). There are concrete stub abutments at the top of each embankment, which support the deck. A four foot section of the left abutment concrete stub is partially undermined, with no sign of piles in the voided area. The undermining has occurred during recent flooding. Some of the boulder fill on the spill-through embankments also lines the banks upstream and downstream from the bridge. Settlement is noted on the report as possible but not clearly visible. (Continued, page 35) 


\section{Bridge Hydrologic Data}

Is there hydrologic data available? $\underline{\mathbf{N}}$ if No, type ctrl-n $h \quad$ VTAOT Drainage area $\left(m i^{2}\right)$ : -

Terrain character:

Stream character \& type: -

Streambed material:

Discharge Data (cfs):

$$
\begin{aligned}
& Q_{2.33}- \\
& Q_{50}-
\end{aligned}
$$

Record flood date $(M M / D D / Y Y)$ :

Estimated Discharge (cfs): Ice conditions (Heavy, Moderate, Light) : -

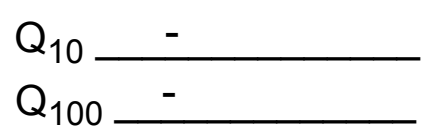

$$
\begin{aligned}
& Q_{25}- \\
& Q_{500}-
\end{aligned}
$$

Water surface elevation $(f t):-$

The stage increases to maximum highwater elevation (Rapidly, Not rapidly):

The stream response is (Flashy, Not flashy):

Describe any significant site conditions upstream or downstream that may influence the stream's stage: -

Watershed storage area (in percent): _ _ \%

The watershed storage area is: - (1-mainly at the headwaters; 2- uniformly distributed; 3-immediatly upstream oi the site)

Water Surface Elevation Estimates for Existing Structure:

\begin{tabular}{|l|l|l|l|l|l|}
\hline Peak discharge frequency & $Q_{2.33}$ & $Q_{10}$ & $Q_{25}$ & $Q_{50}$ & $Q_{100}$ \\
Water surface elevation (ft)) & - & - & - & - & - \\
Velocity (ft/sec) & - & - & - & - & - \\
\hline
\end{tabular}

Long term stream bed changes: -

Is the roadway overtopped below the $\mathrm{Q}_{100}$ ? (Yes, No, Unknown): $\mathbf{U} \quad$ Frequency: Relief Elevation (ft): Discharge over roadway at $Q_{100}\left(f^{3} / \mathrm{sec}\right)$ :

Are there other structures nearby? (Yes, No, Unknown): $\underline{\mathbf{U}}$ Upstream distance (miles): Town: If No or Unknown, type ctrl-n os Highway No. : Structure No. : Year Built:

Clear span (ft): Clear Height $(f t)$ : Full Waterway $\left(f^{2}\right)$ : 
Downstream distance (miles): Town: Year Built:

Highway No. : Structure No. : Structure Type:

Clear span (ft): Clear Height $(f t)$ : Full Waterway $\left(f^{2}\right)$ :

Comments:

The report indicates a 3.5 feet deep scour hole has developed in the channel about 10 feet from the left abutment. This may have resulted in the slumping of the spill-through embankment and the undermining of the concrete abutment footing the report notes. There is some bank erosion noted, but point bars and debris accumulation problems are minor.

\section{USGS Watershed Data}

Watershed Hydrographic Data

Drainage area (DA) 35.91

Watershed storage (ST) $\mathrm{mi}^{2}$ Lake/pond/swamp area 0.55 $\mathrm{mi}^{2}$

Bridge site elevation $\mathbf{7 8 0}$ 1.5 $\%$

Main channel length $\mathbf{1 2 . 2 1}$ $\mathrm{ft}$ Headwater elevation 2267 $\mathrm{ft}$ $10 \%$ channel length elevation $\mathbf{8 1 0}$ $\mathrm{ft} \quad 85 \%$ channel length elevation 1770 $\mathrm{ft}$

Main channel slope (S) 104.83 $\mathrm{ft} / \mathrm{mi}$

Watershed Precipitation Data

Average site precipitation in Average headwater precipitation in

Maximum 2yr-24hr precipitation event $(124,2)$ in

Average seasonal snowfall (Sn) $\mathrm{ft}$ 


\section{Bridge Plan Data}

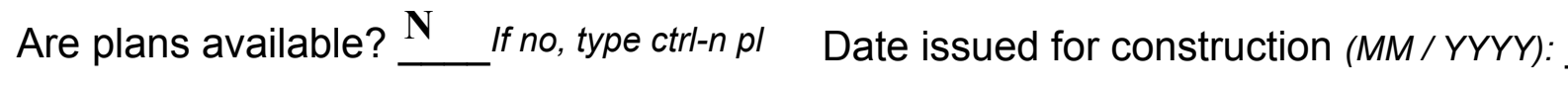

Project Number

Minimum channel bed elevation:

Low superstructure elevation: USLAB DSLAB USRAB DSRAB Benchmark location description:

NO BENCHMARK INFORMATION

Reference Point (MSL, Arbitrary, Other): Datum (NAD27, NAD83, Other):

Foundation Type: 4

If 1 : Footing Thickness

If 2: Pile Type:

If 3: Footing bottom elevation:

Is boring information available? $\mathbf{N}$

Foundation Material Type: $\mathbf{3}$

(1-Spreadfooting; 2-Pile; 3- Gravity; 4-Unknown)

Footing bottom elevation: -

Briefly describe material at foundation bottom elevation or around piles:

NO FOUNDATION MATERIAL INFORMATION

Comments:

NO PLANS. 


\section{Cross-sectional Data}

Is cross-sectional data available? $\mathbf{N}$ If no, type ctrl-n xs

Source (FEMA, VTAOT, Other)? -

Comments: NO ACCURATE CROSS SECTION INFORMATION AVAILABLE.

\begin{tabular}{|l|l|l|l|l|l|l|l|l|l|l|l|}
\hline Station & - & - & - & - & - & - & - & - & - & - & - \\
\hline Feature & - & - & - & - & - & - & - & - & - & - & - \\
\hline $\begin{array}{l}\text { Low chord } \\
\text { elevation }\end{array}$ & - & - & - & - & - & - & - & - & - & - & - \\
\hline $\begin{array}{l}\text { Bed } \\
\text { elevation }\end{array}$ & - & - & - & - & - & - & - & - & - & - & - \\
\hline $\begin{array}{l}\text { Low chord- } \\
\text { bed }\end{array}$ & - & - & - & - & - & - & - & - & - & - & - \\
\hline Station & - & - & - & - & - & - & - & - & - & - & - \\
\hline Feature & - & - & - & - & - & - & - & - & - & - & - \\
\hline $\begin{array}{l}\text { Low chord } \\
\text { elevation }\end{array}$ & - & - & - & - & - & - & - & - & - & - & - \\
\hline $\begin{array}{l}\text { Bed } \\
\text { elevation }\end{array}$ & - & - & - & - & - & - & - & - & - & - & - \\
\hline $\begin{array}{l}\text { Low chord- } \\
\text { bed }\end{array}$ & - & - & - & - & - & - & - & - & - & - & - \\
\hline
\end{tabular}

Source (FEMA, VTAOT, Other)?

Comments: NO CROSS SECTION INFORMATION

\begin{tabular}{|l|l|l|l|l|l|l|l|l|l|l|l|}
\hline Station & - & - & - & - & - & - & - & - & - & - & - \\
\hline Feature & - & - & - & - & - & - & - & - & - & - & - \\
\hline $\begin{array}{l}\text { Low chord } \\
\text { elevation }\end{array}$ & - & - & - & - & - & - & - & - & - & - & - \\
\hline $\begin{array}{l}\text { Bed } \\
\text { elevation }\end{array}$ & - & - & - & - & - & - & - & - & - & - & - \\
\hline $\begin{array}{l}\text { Low chord- } \\
\text { bed }\end{array}$ & - & - & - & - & - & - & - & - & - & - & - \\
\hline Station & - & - & - & - & - & - & - & - & - & - & - \\
\hline Feature & - & - & - & - & - & - & - & - & - & - & - \\
\hline $\begin{array}{l}\text { Low chord } \\
\text { elevation }\end{array}$ & - & - & - & - & - & - & - & - & - & - & - \\
\hline $\begin{array}{l}\text { Bed } \\
\text { elevation }\end{array}$ & - & - & - & - & - & - & - & - & - & - & - \\
\hline $\begin{array}{l}\text { Low chord- } \\
\text { bed }\end{array}$ & - & - & - & - & - & - & - & - & - & - & - \\
\hline
\end{tabular}




\section{APPENDIX E: \\ LEVEL I DATA FORM}


U. S. Geological Survey

Bridge Field Data Collection and Processing Form

Qa/Qc Check by: $\underline{\mathbf{E W}}$

Date: $2 / 21 / 96$

\section{Structure Number}

\section{A. General Location Descriptive}

1. Data collected by (First Initial, Full last name) M. IVANOFF

Date $(M M / D D / Y Y)$

09 / 05

$/ 1995$

2. Highway District Number $\mathbf{0 7}$

County ORANGE (017)

Waterway $(I$ - 6) SOUTH BRANCH WAITS RIVER

Route Number TH 50

3. Descriptive comments:

Located 0.1 miles to junction with Town Highway 2
Mile marker -

Town CORINTH (15700)

Road Name -

Hydrologic Unit Code: $\mathbf{0 1 0 8 0 1 0 3}$

\section{B. Bridge Deck Observations}

\section{Surface cover... $\quad$ LBUS $4 \quad$ RBUS $4 \quad$ LBDS $4 \quad$ RBDS 4 Overall 4}

(2b us,ds,lb,rb: 1- Urban; 2- Suburban; 3- Row crops; 4- Pasture; 5- Shrub- and brushland; 6- Forest; 7- Wetland)

5. Ambient water surface...US $\underline{1}$ UB 1 DS 1 (1-pool; 2- riffle)

6. Bridge structure type 1 (1- single span; 2- multiple span; 3- single arch; 4- multiple arch; 5-cylindrical culvert; 6- box culvert; or 7- other)
7. Bridge length $\mathbf{5 6 . 0}$
(feet)
Span length $\mathbf{5 4 . 0}$
(feet)
Bridge width 11.7 (feet)

\section{Road approach to bridge:}
8. LB 0
RB 0
( 0 even, 1- lower, 2- higher)
9. LB_2
RB $\underline{2}$
(1- Paved, 2- Not paved)

10. Embankment slope (run / rise in feet / foot):
US left
1.9:1
US right 1.9:1

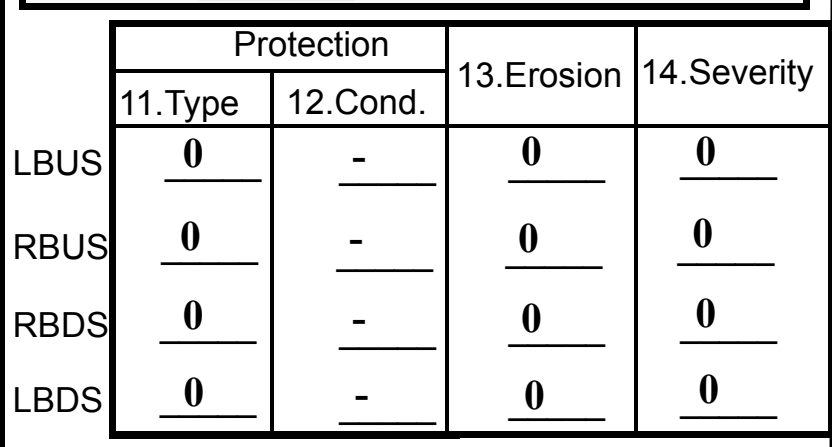

Bank protection types: 0- none; 1- $<12$ inches;

2- < 36 inches; 3- < 48 inches;

4- $<60$ inches; 5- wall / artificial levee

Bank protection conditions: 1- good; 2- slumped;

3- eroded; 4- failed

Erosion: 0 - none; 1- channel erosion; 2-

road wash; 3- both; 4- other

Erosion Severity: 0 - none; 1- slight; 2- moderate;

\section{Channel approach to bridge (BF):}

15. Angle of approach: $\mathbf{2 0}$

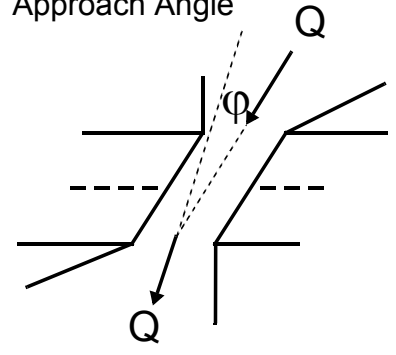

17. Channel impact zone 1:

Where? LB $(L B, R B)$

Range? 10

Channel impact zone 2:

Where? LB (LB, RB)

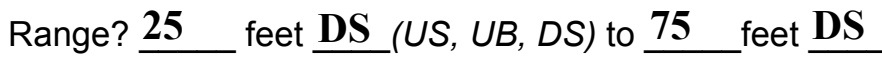

Impact Severity: 0- none to very slight; 1- Slight; 2-Moderate; 3- Severe
16. Bridge skew: $\mathbf{3 0}$ Bridge Skew Angle

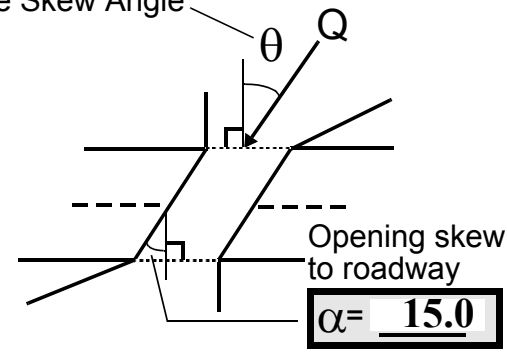

\section{Exist? $\underline{\mathbf{Y}}(\mathrm{Y}$ or $N)$}

Severity 2

S, UB, DS) to $\underline{\mathbf{0}}$ feet $\underline{\mathbf{D S}}$

Exist? $\mathbf{Y}(Y$ or $N)$

Severity 1 
18. Bridge Type: $\mathbf{3}$

1a- Vertical abutments with wingwalls

1 b- Vertical abutments without wingwalls

2- Vertical abutments and wingwalls, sloping embankment

Wingwalls parallel to abut. face

3- Spill through abutments

4- Sloping embankment, vertical wingwalls and abutments

Wingwall angle less than $90^{\circ}$.

1 a with wingwalls

19. Bridge Deck Comments (surface cover variations, measured bridge and span lengths, bridge type variations, approach overflow width, etc.)

\#7: The bridge dimension values are from VTAOT files. The measured values are: bridge width between outer beams is $15.6 \mathrm{ft}$; bridge width of the vehicle deck is $12.1 \mathrm{ft}$; clear span is $52 \mathrm{ft}$.

\section{Upstream Channel Assessment}

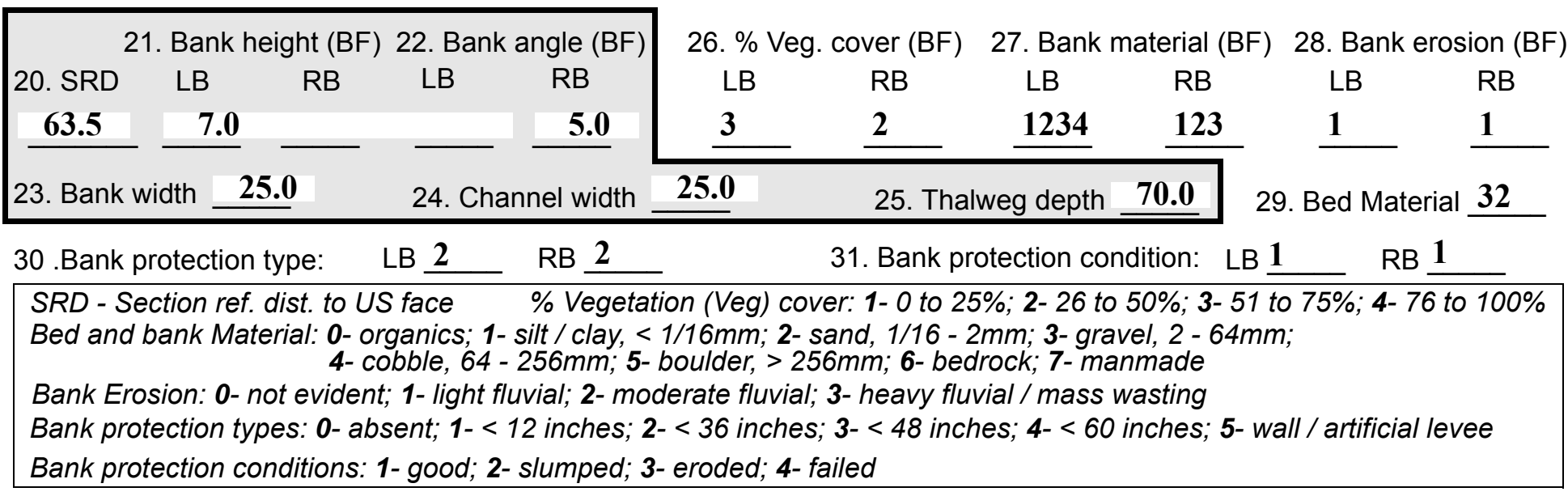

32. Comments (bank material variation, minor inflows, protection extent, etc.):

\#30: The left bank protection extends 12 feet from the bridge.

On the right bank the protection extends 32 feet from the bridge. 
36. Point bar extent: $\underline{\mathbf{2 0 8}}$ feet $\underline{\mathrm{US}}$ (US, UB) to $\underline{\mathbf{5 4}}$ feet $\underline{\mathrm{US}}$ (US, UB, DS) positioned $\underline{\mathbf{0}} \%$ LB to $\underline{\mathbf{7 5}} \%$ RB

37. Material: 32

38. Point or side bar comments (Circle Point or Side; Note additional bars, material variation, status, etc.):

This is a side bar consisting of gravel and some sand.

39. Is a cut-bank present? $\mathbf{Y}$ (Y or if $N$ type $c t r-n c b)$

41. Mid-bank distance: $\mathbf{8 0}$

43. Bank damage: 1

42. Cut bank extent: 90
40. Where? $\mathbf{R B} \quad(L B$ or $R B)$ feet $\underline{\mathbf{U S}}$ (US, UB) to $\underline{\mathbf{3 2}}$ feet $\underline{\mathbf{U S}}$ (US, UB, DS)

44. Cut bank comments (eg. additional cut banks, protection condition, etc.):

Ambient flow is impacting the banks by scalloping the material around a fallen tree.

\section{Is channel scour present? $\mathbf{N}$ ( $Y$ or if $N$ type ctrl-n cs)}

47. Scour dimensions: Length Width -

Depth : -

46. Mid-scour distance: -

48. Scour comments (eg. additional scour areas, local scouring process, etc.):

\section{NO CHANNEL SCOUR}

*See channel scour comment in downstream section.

49. Are there major confluences? $\mathbf{Y}$ ( $Y$ or if $N$ type ctrl- $n m c)$

51. Confluence 1: Distance $2 \mathbf{2 4 0}$

Confluence 2: Distance -
52. Enters on $\underline{\mathbf{R B}}$ ( $L B$ or $R B)$

Enters on ( $L B$ or $R B)$

54. Confluence comments (eg. confluence name):

Minor confluence.

\section{Under Bridge Channel Assessment}

55. Channel restraint (BF)? LB 1

\begin{tabular}{|ccccc}
\hline \multicolumn{2}{|c}{ 56. Height (BF) } & \multicolumn{2}{c}{57 Angle (BF) } \\
LB & RB & LB & RB \\
43.5 & & 0.5 &
\end{tabular}

58. Bank width (BF) -

(1- natural bank; 2- abutment; 3- artificial levee)

50. How many? 1

53. Type 1 (1- perennial; 2- ephemeral)

Type (1- perennial; 2- ephemeral) $\% \mathrm{RB}$ 
65. Debris and Ice Is there debris accumulation?

(Yor $N)$ 66. Where? $\underline{Y}$

(1- Upstream; 2- At bridge; 3- Both)

67. Debris Potential 1 (1-Low; 2-Moderate; 3- High)

68. Capture Efficiency 2

(1-Low; 2- Moderate; 3- High)

69. Is there evidence of ice build-up? 1 (Y or N)

Ice Blockage Potential $\mathbf{N}$

(1- Low; 2- Moderate; 3- High)

70. Debris and Ice Comments:

1

\#66: Debris exists along the banks both upstream and downstream.

\#67: Banks are well vegetated with small trees and brush, some of which are leaning into the channel.

\begin{tabular}{|l|c|c|c|c|c|c|c|c|}
\hline Abutments & $\begin{array}{c}\text { 71. Attack } \\
\angle \mathrm{BF})\end{array}$ & $\begin{array}{c}72 . \text { Slope } \\
(\mathrm{Qmax})\end{array}$ & $\begin{array}{l}\text { 73. Toe } \\
\text { loc. (BF) }\end{array}$ & $\begin{array}{c}\text { 74. Scour } \\
\text { Condition }\end{array}$ & $\begin{array}{c}\text { 75. Scour } \\
\text { depth }\end{array}$ & $\begin{array}{c}\text { 76. Exposure } \\
\text { depth }\end{array}$ & 77. Material & 78. Length \\
\hline LABUT & & $\mathbf{2 5}$ & $\mathbf{3 0}$ & $\mathbf{2}$ & $\mathbf{0}$ & $\mathbf{0}$ & $\mathbf{0}$ & $\mathbf{9 0 . 0}$ \\
\hline RABUT & $\mathbf{1}$ & $\mathbf{0}$ & $\mathbf{3 0}$ & & & $\mathbf{2}$ & $\mathbf{0}$ & $\mathbf{4 9 . 5}$ \\
\hline
\end{tabular}

Pushed: $L B$ or RB

Toe Location (Loc.): 0- even, 1- set back, 2- protrudes

Scour cond.: 0- not evident; 1- evident (comment); 2- footing exposed; 3-undermined footing; 4- piling exposed; 5- settled; 6- failed

Materials: 1- Concrete; 2- Stone masonry or drywall; 3- steel or metal; 4- wood

79. Abutment comments (eg. undermined penetration, unusual scour processes, debris, etc.):

0

0

1

The structural inspection of $6 / 29 / 93$ noted undermining at the left abutment. Stone fill is now in place at the base of the left and right concrete abutments and creates spill-through embankments.

80. Wingwalls:

Exist? Material? Scour Scour Exposure $\begin{aligned} & 81 . \\ & \text { Angle? Length? }\end{aligned}$ Condition? depth? depth?

USLWW:

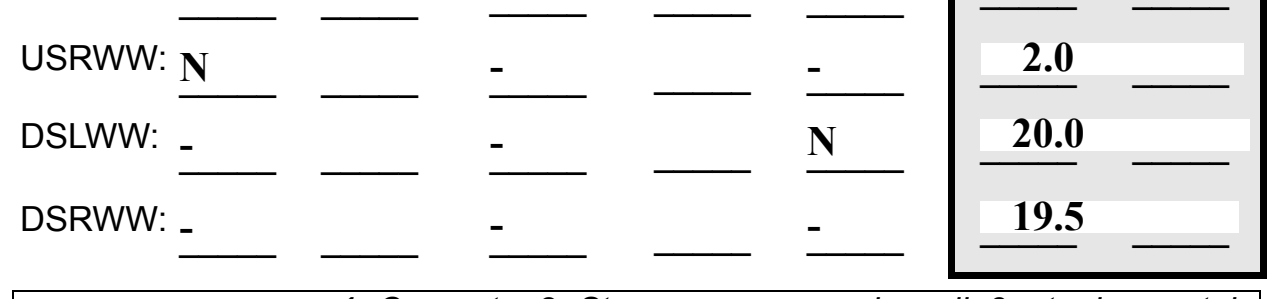

Wingwall materials: 1- Concrete; 2- Stone masonry or drywall; 3- steel or metal; 4- wood

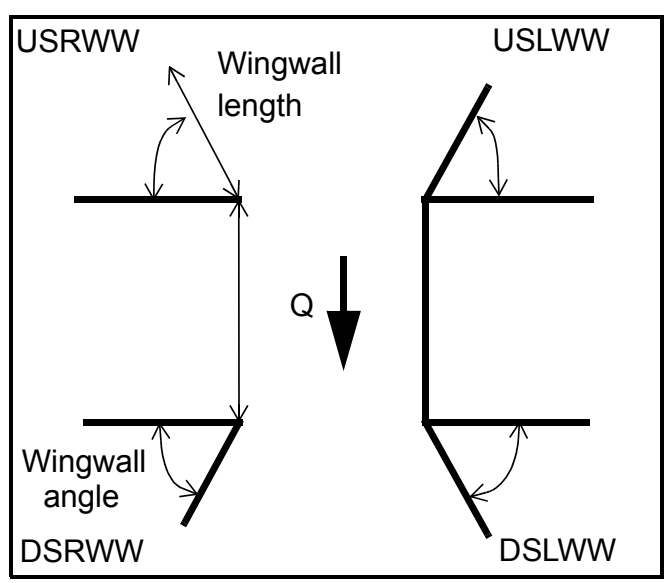

82. Bank / Bridge Protection:

\begin{tabular}{|l|l|l|l|l|l|l|l|c|}
\hline Location & USLWW & USRWW & LABUT & RABUT & LB & RB & DSLWW & DSRWW \\
\hline Type & - & - & $\mathbf{N}$ & - & - & - & $\mathbf{1}$ & $\mathbf{1}$ \\
\hline Condition & $\mathbf{N}$ & - & - & - & - & - & $\mathbf{1}$ & $\mathbf{1}$ \\
\hline Extent & - & - & - & $\mathbf{0}$ & $\mathbf{0}$ & $\mathbf{2}$ & $\mathbf{2}$ & - \\
\hline
\end{tabular}

Bank / Bridge protection types: 0- absent; 1- < 12 inches; 2- < 36 inches; 3- < 48 inches; 4- < 60 inches; 
83. Wingwall and protection comments (eg. undermined penetration, unusual scour processes, etc.):

-
-
-
-
-
-
-
-
-

\section{Piers:}

84. Are there piers? Th (Y or if N type ctrl-n pr)

\begin{tabular}{|l|l|l|l|l|l|l|l|}
\hline \multirow{2}{*}{$\begin{array}{l}85 . \\
\text { Pier no. }\end{array}$} & \multicolumn{3}{|c|}{ width (w) feet } & \multicolumn{3}{c|}{ elevation (e) feet } \\
\cline { 2 - 9 } & w1 & w2 & w3 & e@w1 & e@w2 & e@w3 \\
\hline Pier 1 & - & - & - & - & - & - \\
\hline Pier 2 & - & - & - & - & - & - \\
\hline Pier 3 & - & - & - & - & - & - \\
\hline Pier 4 & - & - & - & - & - & - \\
\hline
\end{tabular}

\begin{tabular}{|l|l|l|l|l|}
\hline Level 1 Pier Descr. & \multicolumn{1}{|c|}{1} & \multicolumn{1}{|c|}{2} & \multicolumn{1}{|c|}{3} & \multicolumn{1}{|c|}{4} \\
\hline 86. Location (BF) & ere are & set & pro- & ream \\
\hline 87. Type & no & back & tec- & and \\
\hline 88. Material & wing & on & tion & dow \\
\hline 89. Shape & walls & the & exte & nstre \\
\hline 90. Inclined? & The & spill- & ndin & am \\
\hline 91. Attack $\angle$ (BF) & ver- & thro & g & thro \\
\hline 92. Pushed & tical & ugh & alon & ugh \\
\hline 93. Length (feet) & - & - & - & - \\
\hline 94. \# of piles & con- & emb & g & the \\
\hline 95. Cross-members & crete & ank- & both & brid \\
\hline 96. Scour Condition & abut & ment & bank & ge. \\
\hline 97. Scour depth & ment & s & s & \\
\hline 98. Exposure depth & s are & with & upst & \\
\hline
\end{tabular}

LFP, LTB, LB, MCL, MCM, MCR, RB, RTB, RFP

1- Solid pier, 2- column, 3- bent

1-Wood; 2- concrete; 3- metal; 4- stone

1- Round; 2- Square; 3- Pointed

Y-yes; $N-$ no

$L B$ or $R B$

0- none; 1- laterals; 2- diagonals; 3- both

0- not evident; 1- evident (comment);

2- footing exposed; 3- piling exposed;

4- undermined footing; 5- settled; 6- failed 
99. Pier comments (eg. undermined penetration, protection and protection extent, unusual scour processes, etc.):

$\mathbf{N}$

100.

\section{E. Downstream Channel Assessment}

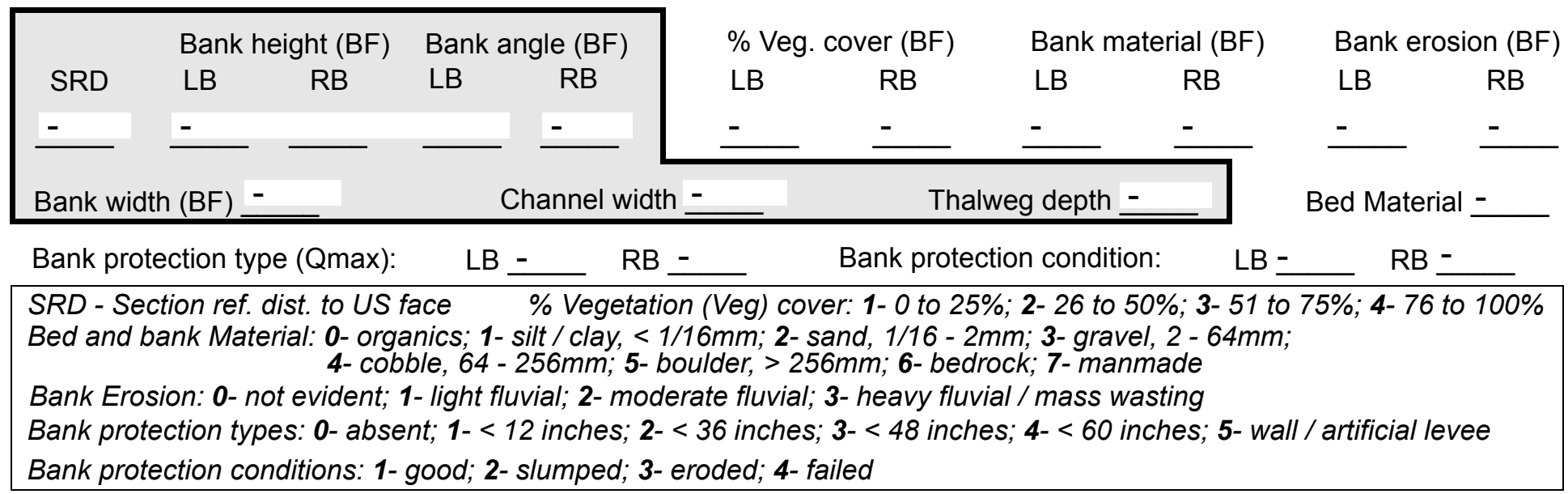

Comments (eg. bank material variation, minor inflows, protection extent, etc.):$$
-
$$$$
-
$$

$-$

$-$

$-$

$-$

$-$

$-$

$-$

$-$

$-$

$-$

$-$

$-$

$-$

\section{Is a drop structure present? __ ( $Y$ or $N$, if $N$ type ctrl-n ds) 102. Distance: ___ feet}

103. Drop: -_ feet 104. Structure material: ___ (1- steel sheet pile; 2- wood pile; 3- concrete; 4- other)

105. Drop structure comments (eg. downstream scour depth):

$-$

$-$

$-$

-

-

- 
106. Point/Side bar present? (Y or $N$. if $N$ type ctrl-n pb)Mid-bar distance:

Mid-bar width: -

Point bar extent: feet -

(US, UB, DS) to feet (US, UB, DS) positioned $\%$ LB to $\% \mathrm{RB}$ Material:

Point or side bar comments (Circle Point or Side; note additional bars, material variation, status, etc.):

$-$

\section{NO PIERS}

Is a cut-bank present? ( $Y$ or if $N$ type ctrl- $n$ cb) Where? (LB or $R B)$

Mid-bank distance:

Cut bank extent: feet (US, UB, DS) to feet (US, UB, DS)

Bank damage: (1- eroded and/or creep; 2- slip failure; 3- block failure)

Cut bank comments (eg. additional cut banks, protection condition, etc.):

2

1

32

314

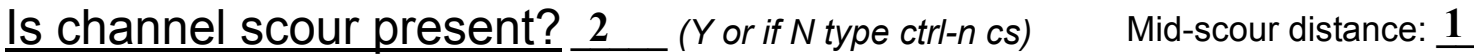

Scour dimensions: Length 23 Width 2 Depth: 2

Positioned 1 \%LB to $\underline{\mathbf{2}} \%$ RB

Scour comments (eg. additional scour areas, local scouring process, etc.):

Protection on the right bank extends $10 \mathrm{ft}$ downstream from the bridge. Protection on the left bank extends 25 ft from the bridge.

\section{Are there major confluences?} ( $Y$ or if $N$ type ctrl-n $m c)$

How many?

Confluence 1: Distance Enters on $(L B$ or $R B)$

Type (1-perennial; 2- ephemeral)

Confluence 2: Distance

Enters on (LB or $R B)$

Type (1- perennial; 2- ephemeral)

Confluence comments (eg. confluence name):

\section{F. Geomorphic Channel Assessment}

107. Stage of reach evolution
1- Constructed

2- Stable

3- Aggraded

4- Degraded

5- Laterally unstable

6- Vertically and laterally unstable 
108. Evolution comments (Channel evolution not considering bridge effects; See HEC-20, Figure 1 for geomorphic descriptors):

$\mathbf{N}$

$-$

NO DROP STRUCTURE

Y

170

25

75

DS 


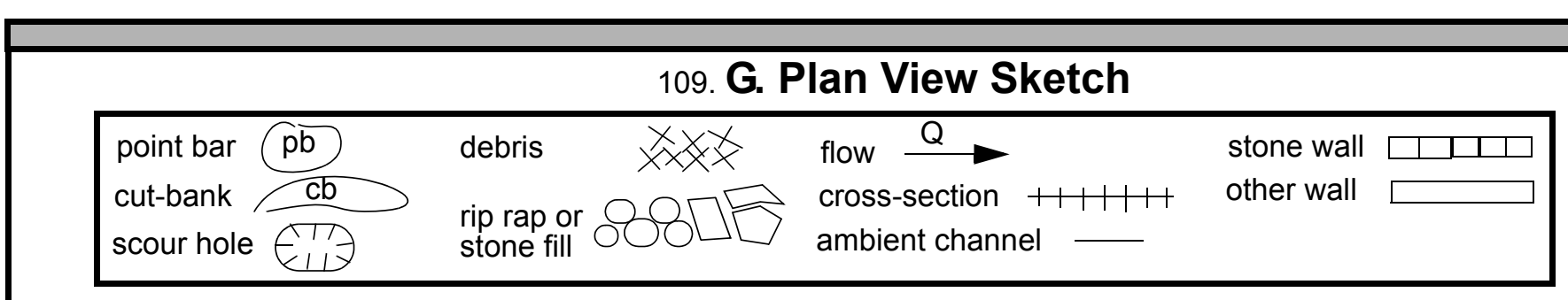


APPENDIX F:

SCOUR COMPUTATIONS 


\begin{tabular}{|c|c|c|c|}
\hline $\begin{array}{l}\text { Structure Number: } \text { CORITH00500034 } \\
\text { Road Number: }\end{array}$ & & $\begin{array}{l}\text { Town: } \\
\text { County: }\end{array}$ & $\begin{array}{l}\text { Corinth } \\
\text { Orange }\end{array}$ \\
\hline Stream: South Branch Waits River & & & \\
\hline Initials MAI & Checked: & RLB & \\
\hline nalysis of contraction scour, liv & -bed or $\mathrm{C}$ & lear wate & \\
\hline $\begin{array}{l}\text { Critical Velocity of Bed Material } \\
\text { VC=11.21*V1^0.1667*D50^0.33 with S }\end{array}$ & converted & to Engl & sh units \\
\hline (Richardson and others, 1995, p. 2 & eq. 16$)$ & & \\
\hline pproach section & & & \\
\hline Characteristic & $100 \mathrm{yr}$ & $500 \mathrm{yr}$ & other $Q$ \\
\hline Total discharge, cfs & 5450 & 8200 & 1830 \\
\hline Main Channel Area, ft2 & 567 & 610 & 433 \\
\hline Left overbank area, ft2 & 2112 & 2501 & 978 \\
\hline Right overbank area, ft2 & 396 & 552 & 63 \\
\hline Top width main channel, ft & 70 & 70 & 70 \\
\hline Top width L overbank, ft & 620 & 636 & 568 \\
\hline Top width $\mathrm{R}$ overbank, ft & 237 & 266 & 102 \\
\hline D50 of channel, ft & 0.0777 & 0.0777 & 0.0777 \\
\hline D50 left overbank, ft & -- & -- & -- \\
\hline D50 right overbank, ft & -- & -- & -- \\
\hline Y1, average depth, MC, ft & 8.1 & 8.7 & 6.2 \\
\hline Y1, average depth, LOB, ft & 3.4 & 3.9 & 1.7 \\
\hline $\mathrm{y}_{1}$, average depth, $\mathrm{ROB}$, ft & 1.7 & 2.1 & 0.6 \\
\hline Total conveyance, approach & 337096 & 435219 & 118016 \\
\hline Conveyance, main channel & 72085 & 81508 & 46060 \\
\hline Conveyance, LOB & 237282 & 309043 & 69661 \\
\hline Conveyance, ROB & 27729 & 44669 & 2295 \\
\hline Percent discrepancy, conveyance & 0.0000 & -0.0002 & 0.0000 \\
\hline Qm, discharge, MC, cfs & 1165.4 & 1535.7 & 714.2 \\
\hline Q1, discharge, LOB, cfs & 3836.3 & 5822.7 & 1080.2 \\
\hline Qr, discharge, ROB, cfs & 448.3 & 841.6 & 35.6 \\
\hline Vm, mean velocity $M C$, ft/s & 2.1 & 2.5 & 1.6 \\
\hline VI, mean velocity, LOB, ft/s & 1.8 & 2.3 & 1.1 \\
\hline Vr, mean velocity, ROB, ft/s & 1.1 & 1.5 & 0.6 \\
\hline Vc-m, crit. velocity, MC, ft/s & 6.8 & 6.9 & 6.5 \\
\hline Vc-l, crit. velocity, LOB, ft/s & $\mathrm{ERR}$ & ERR & $\mathrm{ERR}$ \\
\hline Vc-r, crit. velocity, ROB, ft/s & ERR & ERR & ERR \\
\hline Results & & & \\
\hline Live-bed(1) or Clear-Water(0) Cont & action $\mathrm{Sc}$ & our? & \\
\hline Main Channel & 0 & 0 & 0 \\
\hline Left Overbank & $\mathrm{N} / \mathrm{A}$ & $\mathrm{N} / \mathrm{A}$ & $\mathrm{N} / \mathrm{A}$ \\
\hline Right Overbank & $\mathrm{N} / \mathrm{A}$ & $\mathrm{N} / \mathrm{A}$ & $\mathrm{N} / \mathrm{A}$ \\
\hline
\end{tabular}


Clear water Contraction Scour in MAIN CHANNEL

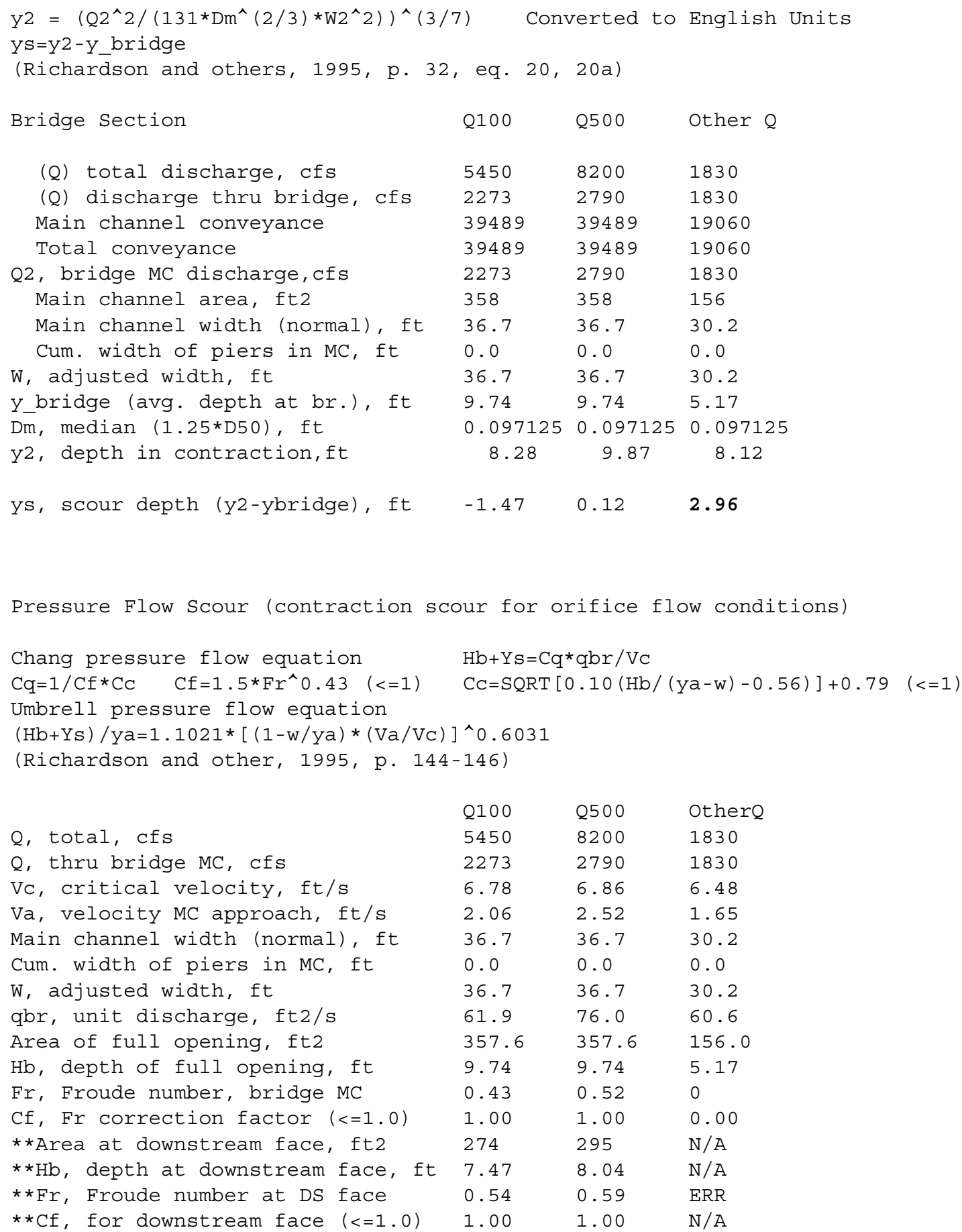




$\begin{array}{llll}\text { Elevation of Low Steel, ft } & 502.67 & 502.67 & 0 \\ \text { Elevation of Bed, ft } & 492.93 & 492.93 & -5.17 \\ \text { Elevation of Approach, ft } & 503.56 & 504.18 & 0 \\ \text { Friction loss, approach, ft } & 0.12 & 0.19 & 0 \\ \text { Elevation of WS immediately US, ft } & 503.44 & 503.99 & 0.00 \\ \text { ya, depth immediately US, ft } & 10.51 & 11.06 & 5.17 \\ \text { Mean elevation of deck, ft } & 506.1 & 506.1 & 0 \\ \text { w, depth of overflow, ft (>=0) } & 0.00 & 0.00 & 0.00 \\ \text { CC, vert contrac correction (<=1.0) } & 0.98 & 0.97 & 1.00 \\ \text { *CC, for downstream face (<=1.0) } & 0.912517 & 0.919043 & \text { ERR } \\ \text { Ys, scour w/Chang equation, ft } & -0.44 & 1.69 & \mathrm{~N} / \mathrm{A} \\ \text { Ys, scour w/Umbrell equation, ft } & -4.10 & -3.08 & \mathrm{~N} / \mathrm{A}\end{array}$

**=for UNsubmerged orifice flow using estimated downstream bridge face properties.

**Ys, scour w/Chang equation, ft $2.55 \quad 4.02 \quad \mathrm{~N} / \mathrm{A}$

**Ys, scour w/Umbrell equation, ft $-1.82 \quad-1.38$ ERR

In UNsubmerged orifice flow, an adjusted scour depth using the Laursen equation results and the estimated downstream bridge face properties can also be computed (ys=y2-ybridgeDS)

$\begin{array}{llll}\text { Y2, from Laursen's equation, ft } & 8.28 & 9.87 & 8.12 \\ \text { WSEL at downstream face, ft } & 500.99 & 501.42 & -- \\ \text { Depth at downstream face, ft } & 7.47 & 8.04 & \text { N/A } \\ \text {, depth of scour (Laursen), ft } & 0.81 & 1.83 & \text { N/A }\end{array}$

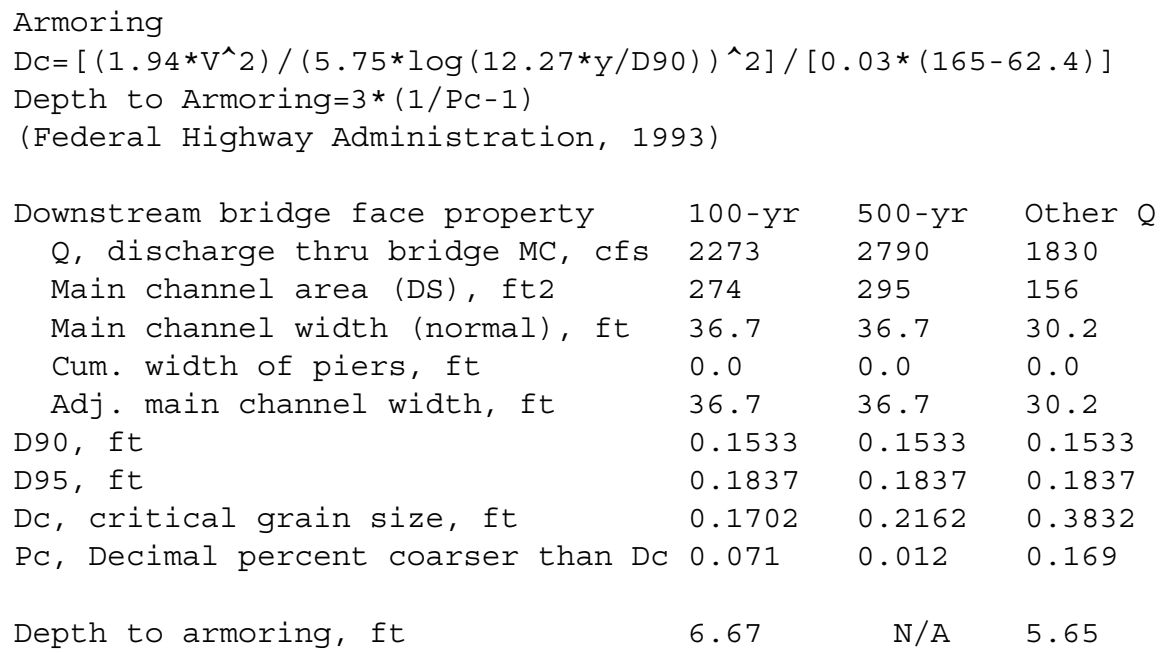

Abutment Scour

Froehlich's Abutment Scour

$\mathrm{Ys} / \mathrm{Y} 1=2.27 * \mathrm{~K} 1 * \mathrm{~K} 2 *\left(\mathrm{a}^{\prime} / \mathrm{Y} 1\right)^{\wedge} 0.43 * \mathrm{Fr} 1 \wedge 0.61+1$

(Richardson and others, 1995, p. 48, eq. 28)

Characteristic $a^{\prime}$, abut.length blocking flow, ft

Ae, area of blocked flow ft2

Qe, discharge blocked abut., cfs (If using Qtotal_overbank to obtain Ve, leave Qe blank and enter Ve and Fr manually)
Right Abutment

$\begin{array}{cccccc}5450 & 8200 & 1830 & 5450 & 8200 & 1830 \\ 627.2 & 643.9 & 578.5 & 262.6 & 291.3 & 130.7 \\ 1529.68 & 1641.12 & 1064.67 & 520.32 & 701.25 & 156.98 \\ -- & -- & 1245.12 & 630.59 & -- & 131.61\end{array}$




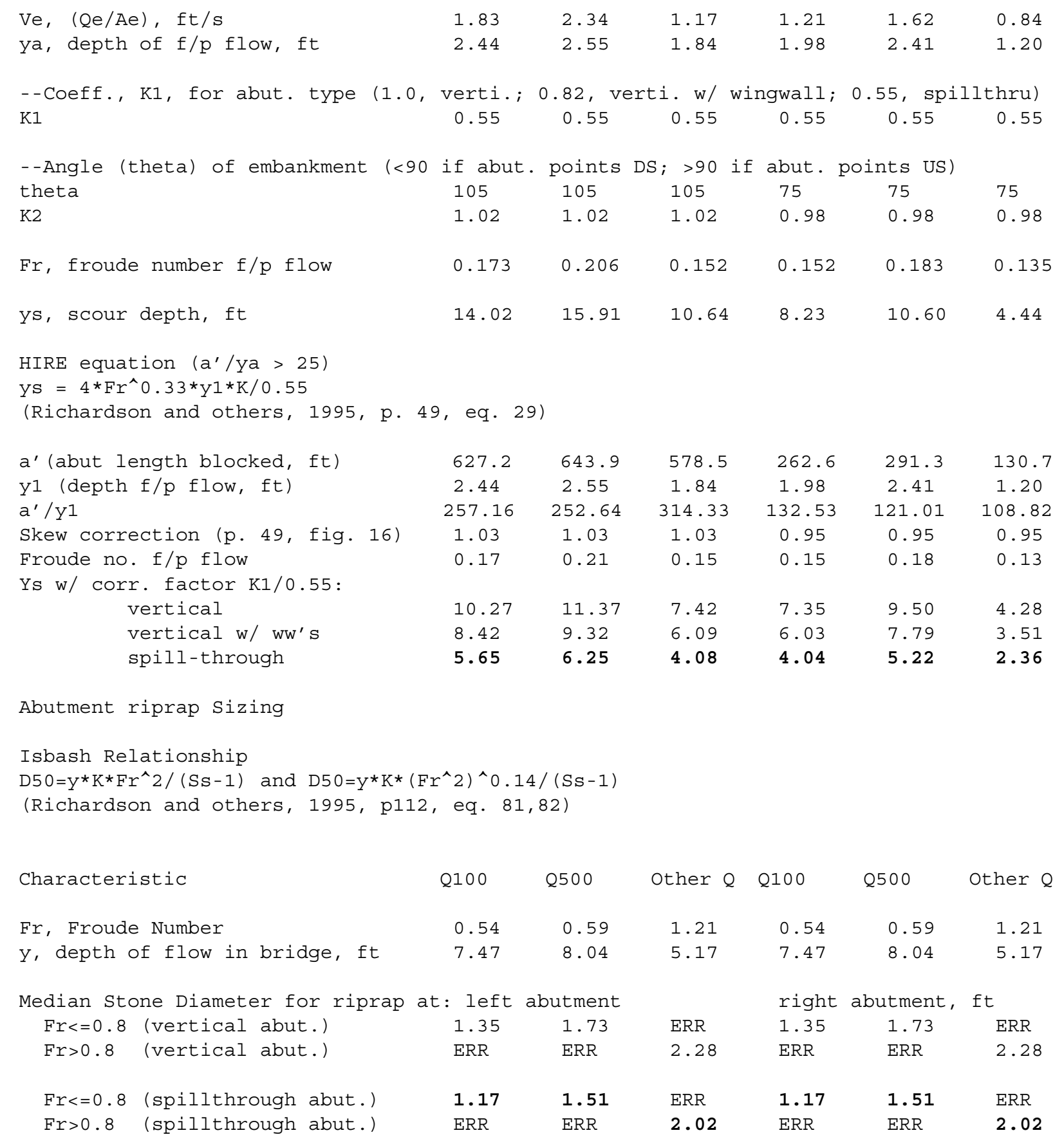


